\title{
From biota to chemistry and climate: towards a comprehensive description of trace gas exchange between the biosphere and atmosphere
}

\author{
A. Arneth ${ }^{1}$, S. Sitch ${ }^{2,3}$, A. Bondeau ${ }^{4}$, K. Butterbach-Bahl ${ }^{5}$, P. Foster ${ }^{6}$, N. Gedney ${ }^{2}$, N. de Noblet-Ducoudré ${ }^{7}$, \\ I. C. Prentice ${ }^{6}$, M. Sanderson ${ }^{8}$, K. Thonicke ${ }^{4}$, R. Wania ${ }^{9}{ }^{*}$, and S. Zaehle ${ }^{10}$ \\ ${ }^{1}$ Department of Physical Geography and Ecosystem Analysis, Lund University, Lund, Sweden \\ ${ }^{2}$ Met Office Hadley Centre, Joint Centre of Hydrometeorological Research, Wallingford, UK \\ ${ }^{3}$ School of Geography, University of Leeds, LS2 9JT, UK \\ ${ }^{4}$ Potsdam Institute for Climate Impact Research, P.O. Box 6012 03, 14412 Potsdam, Germany \\ ${ }^{5}$ Forschungszentrum Karlsruhe, Institute for Meteorology and Climate Research (IMK-IFU), Kreuzeckbahnstr. 19, 82467 \\ Garmisch-Partenkirchen, Germany \\ ${ }^{6}$ QUEST, Department of Earth Sciences, University of Bristol, Wills Memorial Building, Queens Road, Bristol, BS8 1RJ, UK \\ ${ }^{7}$ Laboratoire des Sciences du Climat et de l'Environnement (LSCE), Orme des Merisiers, Bat. 71291191 \\ GIF-SUR-YVETTE CEDEX, France \\ ${ }^{8}$ Met Office Hadley Centre, Exeter, UK \\ ${ }^{9}$ Department of Earth Sciences, University of Bristol, Wills Memorial Building, Queens Road, Bristol, BS8 1RJ, UK \\ ${ }^{10}$ Max Planck Institute for Biogeochemistry, Department for Biogeochemical Systems, Hans-Knöll-Str. 10, \\ 07745 Jena, Germany \\ *now at: School of Earth and Ocean Sciences, University of Victoria, BC, V8N 1P8, Canada
}

Received: 1 July 2009 - Published in Biogeosciences Discuss.: 30 July 2009

Revised: 17 December 2009 - Accepted: 18 December 2009 - Published: 12 January 2010

\begin{abstract}
Exchange of non- $\mathrm{CO}_{2}$ trace gases between the land surface and the atmosphere plays an important role in atmospheric chemistry and climate. Recent studies have highlighted its importance for interpretation of glacial-interglacial ice-core records, the simulation of the pre-industrial and present atmosphere, and the potential for large climate-chemistry and climate-aerosol feedbacks in the coming century. However, spatial and temporal variations in trace gas emissions and the magnitude of future feedbacks are a major source of uncertainty in atmospheric chemistry, air quality and climate science. To reduce such uncertainties Dynamic Global Vegetation Models (DGVMs) are currently being expanded to mechanistically represent processes relevant to non- $\mathrm{CO}_{2}$ trace gas exchange between land biota and the atmosphere. In this paper we present a review of im-
\end{abstract}

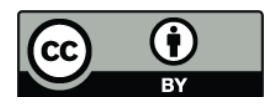

Correspondence to: A. Arneth (almut.arneth@nateko.lu.se) portant non- $\mathrm{CO}_{2}$ trace gas emissions, the state-of-the-art in DGVM modelling of processes regulating these emissions, identify key uncertainties for global scale model applications, and discuss a methodology for model integration and evaluation.

\section{Introduction}

Numerous exchange processes take place between the terrestrial biota and the atmosphere that contribute to the regulation of the climate system on timescales from hours to millennia. Frequently highlighted examples are the partitioning of available energy into sensible and latent heat and the uptake and release of carbon dioxide. The former influences the height of the convective boundary layer and the moisture content of the troposphere, thus affecting cloud formation (Pielke et al., 1998; Levis et al., 2000), while the latter drives seasonality and interannual variability of the atmospheric $\mathrm{CO}_{2}$

Published by Copernicus Publications on behalf of the European Geosciences Union. 
concentration (Ciais et al., 1995; Denning and Fung, 1995; Keeling et al., 1996). Land surface models describe terrestrial biosphere processes within the climate system and have been expanded to include models of dynamic vegetation and interactive carbon cycles. Indeed, climate model experiments that include an interactive terrestrial carbon cycle have demonstrated potentially large climatecarbon cycle feedbacks that have to be taken into account for future climate projections (Cox et al., 2000; Friedlingstein et al., 2001, 2006).

The need to better quantify trace gas exchange at the land surface has spurred the development of dynamic global vegetation models (DGVMs) (Prentice et al., 2007) which include mechanistic representations of terrestrial biogeochemical cycles and vegetation dynamics. The first generation of DGVMs simulated the global distribution of natural vegetation, represented by a number of generic plant functional types (PFTs), and land carbon and hydrological cycles from diurnal to century timescales. The different processes represented by DGVMs are being expanded substantially to account for the crucial role of terrestrial biota in the regulation of atmospheric composition and climate that goes well beyond that of $\mathrm{CO}_{2}$ and the surface energy balance. Important gases in this context are methane $\left(\mathrm{CH}_{4}\right)$ and nitrous oxide $\left(\mathrm{N}_{2} \mathrm{O}\right)$, both of which are well mixed and potent greenhouse gases (GHGs; Donner and Ramanathan, 1980). Other gaseous species, such as biogenic volatile organic compounds (BVOCs) and the nitrogen oxides $\mathrm{NO}$ and $\mathrm{NO}_{2}$ (together referred to as $\mathrm{NO}_{\mathbf{x}}$ ) are much more reactive in the atmosphere than $\mathrm{CH}_{4}$ and $\mathrm{N}_{2} \mathrm{O}$. BVOCs and $\mathrm{NO}_{\mathrm{x}}$ affect the lifetime of some GHGs (e.g., $\mathrm{CH}_{4}$ ) and are precursors of others, such as tropospheric ozone $\left(\mathrm{O}_{3}\right)$, and of biogenic secondary organic aerosols (SOA; Denmann et al., 2007).

A number of atmospheric feedbacks have been proposed regarding the magnitude and regional patterns of biosphereatmosphere exchange of non- $\mathrm{CO}_{2}$ trace gases (Adams et al., 2001; Gedney et al., 2004; Kulmala et al., 2004; Lerdau, 2007; Sitch et al., 2007). These feedbacks include interactions of these gases and their reaction products with climate, vegetation cover, and the terrestrial cycles of carbon and nitrogen. In addition, emissions of carbonaceous trace gases like $\mathrm{CH}_{4}$ and isoprene (a highly reactive and important BVOC) can under certain conditions be large enough to impact the interpretation of carbon cycle measurements. Isoprene emissions are of the order $1 \%$ of the total carbon assimilated by vegetation (i.e., gross primary productivity) but up to $10 \%$ of net ecosystem-atmosphere carbon exchange, NEE (Guenther, 2002). Due to the decoupling of assimilation rates and isoprene emissions under certain conditions this proportion may increase under climate change (Guenther, 2002; Pegoraro et al., 2005; Arneth et al., 2007a). Few studies consider both $\mathrm{CO}_{2}$ and $\mathrm{CH}_{4}$ in the context of an ecosystem carbon balance even though $\mathrm{CH}_{4}$ losses may account for 10$20 \%$ of NEE (Friborg et al., 2003; Grant et al., 2003).
Recent developments in DGVMs aim to represent emissions of climatically relevant non- $\mathrm{CO}_{2}$ trace gases, to investigate future changes in emissions and associated climatechemistry feedbacks systematically within unified modelling frameworks. Key processes include interactive carbon and nitrogen cycles, inclusion of fire disturbance, natural wetlands, land use and land cover changes, mechanistic representations of plant BVOC emissions and plant-ozone interactions. We begin with a short overview of the importance of non- $\mathrm{CO}_{2}$ trace-gas exchange at the land surface for atmospheric chemistry and climate. We then present an overview of DGVM principles, followed by recent developments within the terrestrial biosphere community in expanding DGVMs to incorporate mechanistic, process-based schemes of non- $\mathrm{CO}_{2}$ trace gas exchange, that are of relevance to the atmospheric chemistry-climate modelling community. Developments are grouped according to the introduction of new land cover types and processes into DGVMs (land use, wetlands, nitrogen cycle, wildfire and hydrogen) and advances in modelling plant physiology (relevant for exchange of BVOC, Ozone and dry deposition). We do not provide a comprehensive review of DGVMs and their performance at simulating vegetation dynamics, land- atmosphere $\mathrm{CO}_{2}$ and $\mathrm{H}_{2} \mathrm{O}$ exchange in the context of the terrestrial energy balance or land carbon sink strength, as this has been the focus of earlier studies (Cramer et al., 2001; Sitch et al., 2008). We highlight key uncertainties in our ability to model these processes at the global scale, and make recommendations on future DGVM research in this field.

\section{Importance of non- $\mathrm{CO}_{2}$ trace gas exchange at the land surface for atmospheric chemistry and climate}

\subsection{Non- $\mathrm{CO}_{2}$ trace gas exchange at the land surface}

Terrestrial ecosystems affect tropospheric composition and climate by emitting and/or absorbing GHGs $\left(\mathrm{CO}_{2}, \mathrm{CH}_{4}\right.$, $\mathrm{N}_{2} \mathrm{O}$, and $\mathrm{H}_{2} \mathrm{O}$ ) and other more reactive trace gases (BVOCs, $\mathrm{NO}_{\mathrm{x}}, \mathrm{CO}$, and $\mathrm{H}_{2}$ ). BVOCs also form secondary organic aerosol particles (SOA) by either direct condensation of the BVOC, or the products from chemical reactions. SOA scatter and absorb radiation, and affect cloud formation and precipitation via their ability to act as cloud condensation nuclei (Hoffmann et al., 1997; Hartz et al., 2005; Dusek et al., 2006; Fig. 1). Evapotranspiration determines atmospheric humidity which in turn controls the formation of the hydroxyl radical $(\mathrm{OH})$, the major atmospheric oxidising agent (Derwent, 1995; Monson and Holland, 2001).

Beside $\mathrm{H}_{2} \mathrm{O}$ and $\mathrm{CO}_{2}$ (which are not the focus of this review) the most important GHGs emitted from terrestrial biota are methane $\left(\mathrm{CH}_{4}\right)$ and nitrous oxide $\left(\mathrm{N}_{2} \mathrm{O}\right)$. The chief "natural" biogenic source of $\mathrm{CH}_{4}$ is anaerobic microbial production in wetlands, with emission estimates between 100 and $231 \mathrm{Tg} \mathrm{CH}_{4} \mathrm{a}^{-1}$. These natural emissions contribute no more 


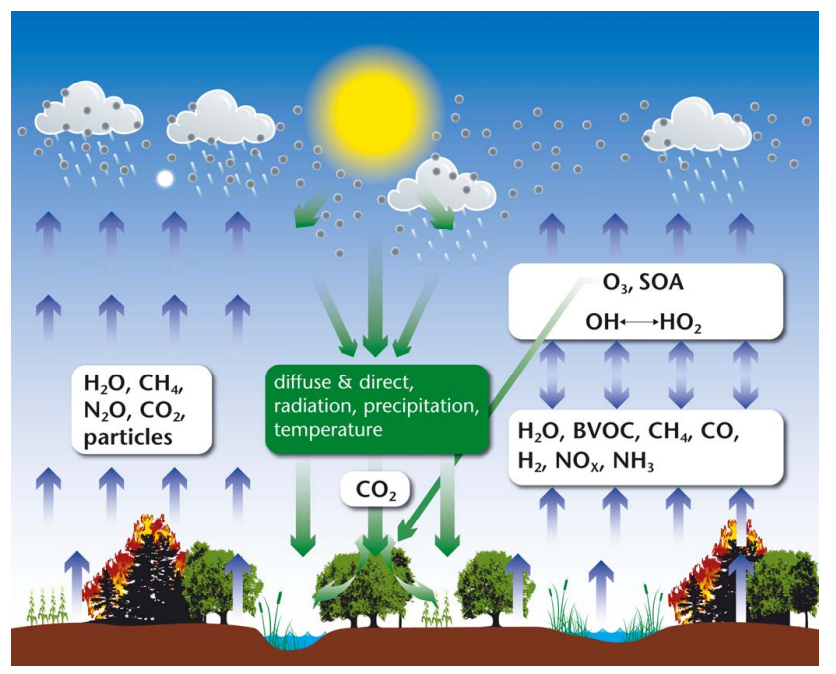

Fig. 1. Conceptual overview of terrestrial carbon cycle - chemistry - climate interactions. The land surface affects atmospheric chemistry and climate directly via surface energy partitioning into latent and sensible heat flux (not shown), and emissions of greenhouse gases $\left(\mathrm{H}_{2} \mathrm{O}, \mathrm{CH}_{4}, \mathrm{~N}_{2} \mathrm{O}, \mathrm{CO}_{2}\right)$ and aerosol particles from forests, grasslands, wetlands, agricultural systems, and vegetation biomass burning. Atmospheric chemistry and climate is also affected by atmospheric reactions of reactive trace gases emitted from vegetation, soils and fires $\left(\mathrm{H}_{2} \mathrm{O}, \mathrm{BVOC}, \mathrm{CH}_{4}, \mathrm{CO}, \mathrm{NO}_{\mathrm{x}}, \mathrm{NH}_{3}, \mathrm{H}_{2}\right)$. These contribute to complex oxidation patterns along variable pathways that depend on the overall chemical and physical environment. Reaction kinetics vary greatly, and the lifetime of substances or their reaction products may vary from seconds (e.g., some BVOC) to years (e.g., $\mathrm{CH}_{4}$ ) which in turn determines whether associated chemistryclimate effects are regional or continental to global. The chief oxidising agent is the hydroxyl radical $\mathrm{OH}$, while some $\mathrm{BVOC}$ react directly with $\mathrm{O}_{3}$. Tropospheric humidity and hence latent heat flux is an important constraint for $\mathrm{OH}$ formation. The main climate relevance of the atmospheric reactions is to consume or generate $\mathrm{O}_{3}$, formation of secondary organic aerosol (SOA), and effects on the lifetime of $\mathrm{CH}_{4}$. Climate feedbacks in the system occur directly (e.g., via the temperature and/or light response of emissions) or indirectly via climate or, for example, $\mathrm{O}_{3}$ effects on vegetation composition, productivity and carbon cycle.

than $15-30 \%$ of the global total $\mathrm{CH}_{4}$ emission flux which is dominated by anthropogenic sources, primarily from rice agriculture, domestic ruminants and energy production (Denman et al., 2007). Smaller sources in natural ecosystems are termites $\left(20 \mathrm{Tg} \mathrm{CH}_{4} \mathrm{a}^{-1}\right)$ and wild ruminants $\left(5 \mathrm{Tg} \mathrm{CH}_{4} \mathrm{a}^{-1}\right.$; Lelieveld et al., 1998). Recent studies suggest a high proportion of $\mathrm{CH}_{4}$ emissions occur from tropical wetlands that are permanently or seasonally inundated (Mikaloff Fletcher et al., 2004a,b; Wang et al., 2004; Chen and Prinn, 2006), owing to a combination of a warm and moist climate and high plant productivity. Estimates of the spatial extent of wetlands which account for seasonal changes in inundation and maximum areas under standing water attribute approxi- mately equal areas to the tropics (including rice paddies) and temperate and boreal regions combined (Prigent et al., 2001). Vegetation composition affects the methane flux to the atmosphere via links with plant productivity and by the proportion of aerenchymatous species present (e.g. mangroves, sedges and rushes), as these species facilitate transport of $\mathrm{CH}_{4}$ from anaerobic soil layers to the atmosphere by-passing aerobic layers and the likelihood of oxidation. Keppler et al. (2006) suggest terrestrial plants could be a source of $\mathrm{CH}_{4}$ under aerobic conditions, although the magnitude of this flux and mechanisms involved have been the focus of much debate (Houweling et al., 2006; Dueck et al., 2007; Ferretti et al., 2007). Recent evidence supports the existence of a photochemical source of methane from fresh or dry plant material that is affected by amount and type of UV radiation (Vigano et al., 2008). The terrestrial biosphere can also act as a sink for atmospheric $\mathrm{CH}_{4}$. However, uptake by well aerated upland soils is estimated to lie between 9 and $47 \mathrm{Tg} \mathrm{CH}_{4} \mathrm{a}^{-1}$ (Curry, 2007; Denman et al., 2007; Dutaur and Verchot, 2007); therefore this mechanism plays only a minor role compared to the dominating chemical methane oxidation sink (via reaction with $\mathrm{OH}$ ) in the troposphere.

Biological $\mathrm{N}_{2}$ fixation is the largest source of nitrogen to natural ecosystems, currently delivering approximately $110 \mathrm{Tg} \mathrm{Na}^{-1}$ (Galloway et al., 2004). This flux is rivalled by the application of reactive $\mathrm{N}$ as fertiliser created from the Haber-Bosch process in addition to approximately $40 \mathrm{Tg} \mathrm{Na}^{-1}$ associated with cultivation of nitrogen fixing plants (e.g. from the legume family, with their symbiotic Nfixing bacteria in root nodules; Galloway et al., 2004, 2008). Plants are able to take up organic nitrogen from symbiosis with $\mathrm{N}_{2}$ fixing bacteria and also directly via root uptake of small-chain organic molecules (Schimel and Bennett, 2004) including proteins (Paungfoo-Lonhienne et al., 2008). More typically, depending on plant species and environmental conditions, $\mathrm{N}$ is taken up through the roots in mineral form as nitrate $\left(\mathrm{NO}_{3}^{-}\right)$or ammonium $\left(\mathrm{NH}_{4}^{+}\right)$ions derived from mineralization. Natural $\mathrm{N}_{2} \mathrm{O}$ emissions, presently about $11 \mathrm{TgN} \mathrm{a}^{-1}$ (Galloway et al., 2004), are mainly associated with nitrification and denitrification processes. The magnitude of emissions depends on the availability of $\mathrm{N}$ for soil microbial processes and on environmental conditions, especially on soil temperature and moisture conditions (Parton et al., 1996; Li et al., 2000). Tropical rainforests, which are primarily not $\mathrm{N}$ limited, grow under conditions of high rainfall and temperature, and support microbial $\mathrm{C}$ as well as $\mathrm{N}$ turnover. Tropical rainforest soils are therefore major sources of $\mathrm{N}_{2} \mathrm{O}$ (Kroeze et al., 1999; Galloway et al., 2004; Werner et al., 2007). But the magnitude of net emissions from particular ecosystems are highly uncertain, owing to the restricted number of measurements, the substantial spatial and temporal variability of fluxes (e.g. Groffman et al., 2006; Seitzinger et al., 2006) and the uncertainty in atmospheric $\mathrm{N}$ deposition effects on soil $\mathrm{N}$ trace gas emissions (Pilegaard et al., 2006). Enhanced soil $\mathrm{N}_{2} \mathrm{O}$ emissions have been reported 
for managed agricultural land, which originate from the increased $\mathrm{N}$ availability following fertilisation (Forster et al., 2007; Crutzen et al., 2008). The main sink for $\mathrm{N}_{2} \mathrm{O}$ is photochemical destruction in the upper troposphere and lower stratosphere, whereas the importance of soils as a sink for $\mathrm{N}_{2} \mathrm{O}$ is still unknown (Chapuis-Lardy et al., 2007).

The terrestrial $\mathrm{N}$ cycle is also a major source of the reactive nitrogen oxides $\mathrm{NO}$ and $\mathrm{NO}_{2}\left(\mathrm{NO}_{\mathrm{x}}\right)$. While $\mathrm{NO}_{\mathrm{x}}$ represents only a minor fraction of the total $\mathrm{N}$ fluxes (normally less than $10 \%$ ), they are fundamental components of tropospheric chemistry. Similar to $\mathrm{N}_{2} \mathrm{O}$, major natural sources of $\mathrm{NO}_{\mathrm{x}}$ are associated with soil nitrification and denitrification processes, and the net flux to the atmosphere is estimated at $5-8 \mathrm{TgN} \mathrm{a}^{-1}$ (Galloway et al., 2004; Denman et al., 2007) but production from biomass burning is also important. On a global scale, emissions from natural sources are much smaller than those from fossil fuel combustion (ca. $25 \mathrm{Tg} \mathrm{N} \mathrm{a}^{-1}$; Jaegle et al., 2005). However, there are indications that the natural flux has been underestimated in the past, owing to the underestimation of the importance and effect of $\mathrm{N}$ deposition and the incompletely understood production mechanism of $\mathrm{NO}_{\mathrm{x}}$ in forest soils (Galloway et al., 2004; Schindlbacher et al., 2004; Pilegaard et al., 2006).

Alongside $\mathrm{NO}_{\mathrm{x}}, \mathrm{BVOCs}$ are an important component of vegetation-chemistry-climate interactions. The term "BVOC" subsumes a vast group of molecules with known (defence, attraction) or debated (range of possible stresstolerances) functions in plants (Penuelas and Llusia, 2004). Emissions of BVOCs are strongly dependent on plant species (Kesselmeier and Staudt, 1999). Research on their effects on tropospheric chemistry and climate has to date concentrated on the subset isoprene $\left(\mathrm{C}_{5} \mathrm{H}_{8}\right)$ and mono- and sesquiterpenes, and their importance for $\mathrm{O}_{3}$ and SOA formation. Isoprene represents approximately one half of the total BVOC emissions (ca. $1000 \mathrm{TgC} \mathrm{a}^{-1}$; Guenther et al., 1995) and in terms of carbon matches, or even exceeds, the annual biogenic $\mathrm{CH}_{4}$ source. Most studies attribute the majority of isoprene emissions to tropical ecosystems, whereas mono- and sesquiterpenes also have sizeable sources in temperate and boreal regions (Guenther et al., 1995; Arneth et al., 2008a; Spracklen et al., 2008). Emissions of some oxygenated BVOCs can also be large (e.g., methanol, Galbally and Kirstine, 2002) but much less is known about the magnitudes of the biogenic sources of these compounds.

Oxidation of hydrocarbons (including BVOCs and $\mathrm{CH}_{4}$ ) is an important source of $\mathrm{CO}$, which in turn is oxidised to $\mathrm{CO}_{2}$ via reaction with $\mathrm{OH}$. This reaction with $\mathrm{OH}$ means that $\mathrm{CO}$ can affect the lifetime of greenhouse gases such as methane. Wild and Prather (2000) estimated that the radiative forcing perturbation caused by an emission of $100 \mathrm{Tg} \mathrm{CO}$ would be the same as that caused by an emission of $5 \mathrm{TgCH}_{4}$. $\mathrm{CO}$ is also emitted directly from both living and decaying vegetation when exposed to sunlight (Warneck, 1999, and references therein), most probably from photooxidation of the plant material, although the exact mechanism is not known.
Source estimates lie in the range 20 to $200 \mathrm{Tg} \mathrm{a}^{-1}$ (Sanderson, 2002). A biological sink of $\mathrm{CO}$ in soils and production during litter decay may also need consideration, although some studies suggest a smaller contribution to the overall budget than previously thought (Potter et al., 1996; King and Crosby, 2002).

Biomass burning releases a large quantity of aerosols and GHGs directly into the atmosphere, together with precursors of these species, many of which also react with the hydroxyl radical (Andreae and Merlet, 2001). Fire emissions have a strong influence on the interannual variation in the atmospheric growth rates of $\mathrm{CO}, \mathrm{CO}_{2}$ and $\mathrm{CH}_{4}$ and are a major source of uncertainty in radiative forcing calculations (Galanter and Levy, 2000; Ito et al., 2007; Naik et al., 2007). Fire is a natural element in major ecosystems, affecting species composition and canopy structure, and thus indirectly trace gas fluxes (Bond-Lamberty et al., 2007). Estimates for late 20th century global fire-related carbon fluxes range between 2 and $4 \mathrm{PgC} \mathrm{a}^{-1}$ (Seiler and Crutzen, 1980; Andreae and Merlet, 2001), representing up to one half of the global $\mathrm{CO}$ emissions into the troposphere (Bian et al., 2007; Duncan et al., 2007). Uncertainties in assessing area burnt, variability of burning conditions and changes in global vegetation productivity are large (Seiler and Crutzen, 1980; Andreae and Merlet, 2001; van der Werf et al., 2004).

Over the last centuries anthropogenic land cover and land use changes following human intervention (e.g. deforestation and expansion of agriculture) have been of increasing importance for trace gas exchange. In some regions, an estimated $80-90 \%$ of all fires are ignited by humans (Denman et al., 2007). Only a few agricultural systems and practices are responsible for half of the anthropogenic $\mathrm{CH}_{4}$ emissions (domestic ruminants, rice paddies, and biomass burning) with emissions from cattle and sheep exceeding those from wild ruminants by a factor of five to ten and rice agriculture adding a further 31 to $112 \mathrm{TgCH}_{4} \mathrm{a}^{-1}$ to the global emission budget (Denman et al., 2007). Significant emissions of $\mathrm{N}_{2} \mathrm{O}$ $\left(3.2 \mathrm{TgN} \mathrm{a}^{-1}\right)$ and $\mathrm{NO}_{\mathrm{x}}\left(2.6 \mathrm{TgN} \mathrm{a}^{-1}\right)$ are related to the use of mineral and organic fertilizers and thus also to livestock density (Galloway et al., 2004). Fertilizer use within agricultural systems, arable soils and pastures are chief sources of reduced $\mathrm{N}$ emissions (referred to as $\mathrm{NH}_{\mathrm{x}}$; Bouwman et al., 2002; Graedel and Crutzen, 1993). Deforestation leads to significant reductions in emissions of isoprene and monoterpenes, which affect regional and potentially global trace gas concentrations. Woody biofuel plantations may increase regional emissions (Lathière et al., 2006; Arneth et al., 2008b); effects of land cover change on emissions of oxygenated BVOC have not yet been extensively studied.

\subsection{Temporal trends in non- $\mathrm{CO}_{2}$ trace gas exchange and their atmospheric burden}

Increases in $\mathrm{CH}_{4}$, tropospheric $\mathrm{O}_{3}$ and $\mathrm{N}_{2} \mathrm{O}$ concentrations since pre-industrial times have contributed (average 
estimate) radiative forcings of $0.48,0.35$ and $0.16 \mathrm{~W} \mathrm{~m}^{-2}$, respectively (Forster et al., 2007). The combined forcing is equivalent to $60 \%$ of the contribution of anthropogenic $\mathrm{CO}_{2}$ to global mean radiative forcing in 2005 (Forster et al., 2007). $\mathrm{N}_{2} \mathrm{O}$ is a greenhouse gas, approximately 298 times more powerful than $\mathrm{CO}_{2}$ (100 year time scale), with an atmospheric lifetime of approximately 114 years and a current rate of atmospheric increase of $0.25 \% \mathrm{a}^{-1}$ (Forster et al., 2007). Its present radiative forcing is about one third of that of $\mathrm{CH}_{4}$. Methane itself is presently the third most important greenhouse gas after water vapour and $\mathrm{CO}_{2}$, having more than doubled in abundance since pre-industrial times (Forster et al., 2007). Annual anthropogenic sources have increased by $50 \%$ since the 18 th century (Denman et al., 2007; Lassey et al., 2007), partially due to agriculture but also due to increased human burning activities. Wetland emissions of $\mathrm{CH}_{4}$, including rice paddies, are projected to approximately double by the end of this century in response to climate change, leading to a positive radiative feedback of nearly 5\% (Gedney et al., 2004). Although $\mathrm{CH}_{4}$ emissions are very sensitive to climate change they have no apparent causal role in the development of late glacial-early interglacial and Holocene climate (Severinghaus et al., 1998; Raynaud et al., 2000). Over the last 10000 years, the impact of $\mathrm{CH}_{4}$ emissions from northern wetlands has been estimated to be a gradually increasing positive radiative forcing, but this reduces the cooling impact of peat $\mathrm{CO}_{2}-\mathrm{C}$ uptake only to minor degree (Frolking and Roulet 2007). Biogeochemical models are unable to reproduce the low $\mathrm{CH}_{4}$ concentrations at the last glacial maximum (LGM) based on changes in global emission patterns alone. An enhanced LGM atmospheric $\mathrm{CH}_{4}$ sink has been invoked due to lower BVOC emissions in the dry, cold environment (Adams et al., 2001; Valdes et al., 2005; Kaplan et al., 2006). However, changes in $\mathrm{NO}_{\mathrm{x}}$ emissions from fire due to climate change and changes in plant $\mathrm{C}: \mathrm{N}$ ratio may also have influenced atmospheric oxidation capacity and $\mathrm{CH}_{4}$ lifetime (Thonicke et al., 2005). In addition, new process understanding in modelling BVOC suggests substantially altered glacial-interglacial emission trends (Possell et al., 2005; Arneth et al., 2007a). Interest in the global $\mathrm{H}_{2}$ cycle has increased as $\mathrm{H}_{2}$ fuel cells have been suggested as a replacement for fossil fuel. With a hydrogen economy some leakage of $\mathrm{H}_{2}$ is inevitable. An estimated leakage of between 3 and $10 \%$ has been associated with an increase of $\mathrm{H}_{2}$ of up to $0.6 \mathrm{ppm}$ (Schultz et al., 2003). Technological and infra-structural issues aside, the impact of an increase in $\mathrm{H}_{2}$ is still uncertain. However, this doubling in $\mathrm{H}_{2}$ concentrations may have the potential to cause reductions in $\mathrm{OH}$, increase lifetimes of $\mathrm{CH}_{4}$, and thus contribute to global warming (Schultz et al., 2003; Warwick et al., 2004).

Over the industrial period precursor emissions from fossil fuel and biomass burning have acted to approximately double the global mean tropospheric $\mathrm{O}_{3}$ concentration (Gauss et al., 2006). This result is subject to a considerable level of uncertainty, as small changes in assumed pre-industrial BVOC to $\mathrm{NO}_{\mathrm{x}}$ ratio, or soil and fire emissions have considerable effect on the pre-industrial $\mathrm{O}_{3}$ burden and hence the preindustrial to present radiative forcing calculations (Mickley et al., 2001; Ito et al., 2007). Uncertainties in future precursor emissions and interactions with climate change, particularly changes in temperature and humidity that affect reaction kinetics paint a complex picture on future regional $\mathrm{O}_{3}$ concentrations (Prather et al., 2001; Dentener et al., 2006a; Liao et al., 2006; Stevenson et al., 2006). Two competing effects determine the net $\mathrm{O}_{3}$ burden: chemical reactions involved in producing $\mathrm{O}_{3}$ will proceed more quickly at higher temperatures, hence greater $\mathrm{O}_{3}$ production. But a warmer climate means increased water vapour in the boundary layer, resulting in greater destruction of $\mathrm{O}_{3}$. There will be additional indirect effects from possibly larger $\mathrm{NO}_{\mathrm{x}}$ emissions from soils, $\mathrm{NO}_{\mathrm{x}}$ by lightning or changes in isoprene production by vegetation. Sanderson et al. (2003a) projected isoprene emissions to increase by nearly $30 \%$ between the 1990 s and 2090 s due to climate change. These increases resulted in projected summer average surface ozone levels over Europe for 2100 to be $8 \mathrm{ppb}$ larger. However this study neither included the effect of BVOC-CO $\mathrm{CO}_{2}$ inhibition in leaves (Sect. 3.6) nor the overall uncertain and contradictory role of VOCs in plant responses to ozone (Fiscus et al., 2005). The former greatly alters future projections of tropospheric $\mathrm{O}_{3}$ and $\mathrm{OH}$ levels with diverging responses in polluted vs. non-polluted regions (Young et al., 2009).

\subsection{Processes in the troposphere}

Almost all chemical degradation of BVOCs and many other species begin via reaction with the hydroxyl radical, $\mathrm{OH}$. The $\mathrm{OH}$ radical is formed during the photolysis of ozone in the presence of water vapour, as illustrated in Fig. 2. Briefly, photolysis of ozone produces an oxygen atom, a proportion of which have sufficient energy to react with water vapour and produce two $\mathrm{OH}$ radicals. Some of these high-energy oxygen atoms are quenched via collision with another air molecule (marked as $\mathrm{M}$ in Fig. 2) back to a ground state, and reform ozone. The formation of $\mathrm{OH}$ is thus principally controlled by the levels of ozone and the flux of radiation.

Other important reactions of BVOCs involve direct oxidation by $\mathrm{O}_{3}$ and the night-time reaction with the $\mathrm{NO}_{3}$ radical. The $\mathrm{NO}_{3}$ radical is formed during the day, but photolyses rapidly, and so its levels are usually very low. At the end of the day, reaction of $\mathrm{NO}_{2}$ with $\mathrm{O}_{3}$ forms $\mathrm{NO}_{3}$ in sufficient levels to oxidise BVOCs. $\mathrm{OH}$ also reacts with other important trace gases such as $\mathrm{CO}$, other VOCs, and $\mathrm{CH}_{4}$. These reactions may, overall, act as sources or sinks of $\mathrm{OH}$, depending on, for example, the levels of $\mathrm{NO}_{\mathrm{x}}$. They strongly control levels of $\mathrm{OH}$ (and hence the oxidising capacity of the troposphere) and the $\mathrm{CH}_{4}$ lifetime (Crutzen, 1979; Derwent, 1995; Lelieveld et al., 1998; Pfeiffer et al., 1998; Wang et al., 1998; Sanderson et al., 2003a; Young et al., 2009). Recently, Lelieveld et al. (2008) measured $\mathrm{OH}$ levels over a 


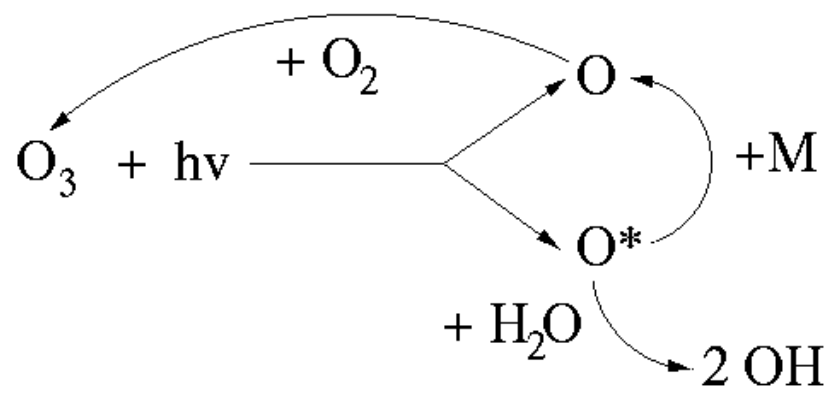

Fig. 2. Production of $\mathrm{OH}$ via photolysis of ozone. The photolysis of ozone $\left(\mathrm{O}_{3}\right)$ produces oxygen atoms in a ground state $(\mathrm{O})$ or higher energy state $\left(\mathrm{O}^{*}\right)$; the latter can react with water vapour to produce $2 \mathrm{OH}$ radicals. Some of the higher energy state oxygen atoms are quenched back to the ground state. The ground state atoms reform ozone.

tropical forest and found they were much higher than model predictions. They proposed that $\mathrm{HO}_{2}$ radicals can react directly with large peroxy radicals produced from VOC degradation to produce significant quantities of $\mathrm{OH}$ radicals under low $\mathrm{NO}_{\mathrm{x}}$ conditions. A modified version of their chemistry scheme including these additional reactions produced $\mathrm{OH}$ levels that were in much better agreement with the measurements. Aerosols produced from the oxidation of BVOCs can act as cloud condensation nuclei, and surfaces for heterogeneous reactions (Andreae and Crutzen, 1997; Kulmala, 2003).

Hydrogen is not a greenhouse gas itself, but reacts with $\mathrm{OH}$ and so may increase concentrations of $\mathrm{CH}_{4}$ and other GHGs. The main source of $\mathrm{H}_{2}$ is the photolysis of formaldehyde ( $\mathrm{HCHO}$ ), produced from the photochemical oxidation of $\mathrm{CH}_{4}$ and VOCs (Price et al., 2007). $\mathrm{H}_{2}$ has small biogenic emission sources associated with biological $\mathrm{N}_{2}$ fixation (Price et al., 2007), wetlands (Conrad, 1996) and biomass burning. While reaction with $\mathrm{OH}$ removes roughly $20 \%$ of atmospheric $\mathrm{H}_{2}$, soil uptake is the dominant sink (Price et al., 2007), the exact magnitude depending on soil type, moisture content and temperature (Yonemura et al., 2000; SmithDowney et al., 2006), or snow cover (Rhee et al., 2006). The present day $\mathrm{H}_{2}$ soil sink is estimated to be $88 \pm 11 \mathrm{Tg} \mathrm{H}_{2} \mathrm{a}^{-1}$ by Rhee et al. (2006) who used seasonal and hemispheric variations in $\mathrm{H}_{2}$ and $\mathrm{D} / \mathrm{H}$ isotopic ratios as constraints. Other estimates range from $40-50$ to $90 \pm 20 \mathrm{Tg} \mathrm{H}_{2} \mathrm{a}^{-1}$ (Seiler and Conrad, 1987; Novelli et al., 1999; Hauglustaine and Ehalt, 2002; Sanderson et al., 2003b; Price et al., 2007) based on measured soil deposition velocities for $\mathrm{H}_{2}$ and estimates of the global areas of various soil types.

Tropospheric $\mathrm{O}_{3}$ is formed during the photochemical oxidation of $\mathrm{CO}, \mathrm{CH}_{4}$, and other VOCs in the presence of $\mathrm{NO}_{\mathrm{x}}$, with an additional source from stratosphere-troposphere exchange (e.g., Stevenson et al., 2006). A recent modelling study by Fiore et al. (2009) has examined the impact of foreign and domestic emissions of $\mathrm{NO}_{\mathrm{x}}, \mathrm{CO}$ and VOCs on ozone levels in four continental-scale regions in the Northern Hemisphere. These authors found that the ozone levels in each region were most sensitive to domestic emissions, but transport of ozone and its precursors from foreign regions was also important. The importance of foreign emissions on domestic ozone levels therefore requires a good understanding of the terrestrial BVOC and $\mathrm{NO}_{\mathrm{x}}$ emission patterns (e.g., Chameides et al., 1988; Pierce et al., 1998; Wang and Shallcross, 2000; Sanderson et al., 2003a; Barket Jr. et al., 2004; von Kuhlmann et al., 2004; Folberth et al., 2006; Wu et al., 2007). Wu et al. (2009) showed that the response of ozone levels to changes in emissions of $\mathrm{NO}_{\mathrm{x}}$ are non-linear outside of the summer months, but are linear during summer, when ozone production is limited by $\mathrm{NO}_{\mathrm{x}}$ levels. The impact of clouds on regional tropospheric ozone budgets has been studied by Voulgarakis et al. (2009). These authors showed that cloud cover can reduce $\mathrm{OH}$ levels and increase isoprene lifetimes by up to 7\%. The largest impacts on ozone levels were seen over some marine regions where cloud optical depths are large. High $\mathrm{O}_{3}$ concentrations $(40 \mathrm{ppb}$ and well above) occur during the northern latitude summer across temperate regions of North America, Eurasia and China, coinciding with the height of the growing season when BVOC emissions, particularly isoprene, are largest. Over tropical regions of India, Amazonia and the Sahel, $\mathrm{O}_{3}$ concentrations peak during the dry season, with biomass burning an important source of precursors, alongside emissions of $\mathrm{NO}_{\mathrm{x}}$ from soils (Kirchhoff et al., 1990; Keller et al., 1991). The most important chemical sink for ozone is photolysis in the presence of water vapour). $\mathrm{O}_{3}$ also reacts directly with BVOCs (Bonn and Moortgat, 2003), and dry deposition accounts for approximately $15 \%$ of the total $\mathrm{O}_{3}$ loss (Stevenson et al., 2006). This process is responsible for the low $\mathrm{O}_{3}$ levels observed during the night-time when a shallow boundary layer develops. Non-stomatal deposition on land surfaces such as plant cuticles or soil constitutes 30 to $80 \%$ of the total deposition sink (Fowler et al., 2001) with surface resistance decreasing with increasing temperature, solar radiation and relative humidity above $60 \%$ (Zhang et al., 2002; Coyle et al., 2009).

$\mathrm{O}_{3}$ enters leaves via the stomata; the primary effect of chronic $\mathrm{O}_{3}$ exposure on plants is to reduce photosynthetic capacity (Ashmore, 2005; Fiscus et al., 2005; Karnosky et al., 2005). However, plants have evolved detoxification mechanisms to counter oxidative stress based on enzymes that utilize ascorbic acid (Plöchl et al., 2000; Fiscus et al., 2005) or possibly BVOCs (Loreto and Velikova, 2001; Fiscus et al., 2005). Reductions in plant assimilation and increasing maintenance costs leads to a reduction in the land carbon sink, and thus implies an indirect radiative forcing of ozone on climate (Sitch et al., 2007).

Secondary organic aerosols, formed as the reaction products of BVOC oxidation, constitute one of the largest uncertainties in the climate system (Forster et al., 2007). SOA affect climate directly by scattering and absorbing radiation, 
and act as efficient cloud condensation nuclei (Hartz et al., 2005; VanReken et al., 2005; Dusek et al., 2006). SOA are important for the growth of particles, if not their formation (Hoffmann et al., 1997; Tsigaridis and Kanakidou, 2003; Tunved et al., 2006). Estimates for the present SOA burden vary by a factor of five (Tsigaridis et al., 2005). A considerable part of this uncertainty relates to the incomplete understanding of the biogenic sources. For instance, until recently oxidation of isoprene was thought to produce negligible amounts of SOA, but recent studies have shown that this is not true (Kroll et al., 2006). Isoprene oxidation is estimated to produce between 4.6 and 6.2 $\mathrm{Tg} \mathrm{SOA} \mathrm{a}^{-1}$ (Henze and Seinfeld, 2006; Tsigaridis and Kanakidou, 2007). The formation of SOA from biogenic precursors depends on the levels of $\mathrm{NO}_{\mathrm{x}}$. For important compounds like isoprene or the terpene $\alpha$-pinene, the SOA yield decreased with increasing levels of $\mathrm{NO}_{\mathrm{x}}$, whereas the reverse is true for some sesquiterpenes (Kroll et al., 2005, 2006; Ng et al., 2007).

Ammonia $\left(\mathrm{NH}_{3}\right)$ has a large agricultural source. Its reaction products (such as $\mathrm{NH}_{4} \mathrm{NO}_{3}$ and $\left(\mathrm{NH}_{4}\right)_{2} \mathrm{SO}_{4}$ ) also form aerosols which play a key role in cloud formation as cloud condensation nuclei. They provide additional aerosol surfaces which may scatter incoming solar radiation which will impact on tropospheric photochemistry. A global modelling study by Feng and Penner (2007) showed that $43 \%$ of the nitrate aerosol and $92 \%$ of the ammonium aerosols exist in the fine mode which scatters radiation most efficiently. The continuing reductions in anthropogenic emissions of $\mathrm{SO}_{2}$ (the main source of sulphate aerosols) means that formation of ammonium nitrate will increase in importance (Pye et al., 2009). The interaction of $\mathrm{HNO}_{3}$ on aerosols has important impacts on tropospheric chemistry. For example, the presence of nitrate in aerosols significantly reduces the conversion of $\mathrm{N}_{2} \mathrm{O}_{5}$ to gaseous $\mathrm{HNO}_{3}$ (Riemer et al., 2003) which in turn reduces tropospheric ozone levels (Tie et al., 2003). Overall, SOA formation patterns differ in polluted and clean air environments which will be important to distinguish, e.g., in simulations of preindustrial aerosol burden and concentrations of cloud condensation nuclei (Andreae, 2007).

\section{Global trace gas exchange modelling}

It is evident that surface-atmosphere exchange processes are important for understanding changes in atmospheric composition and radiative forcing from the last glacial maximum to the present day, and for future projections. Biosphereatmosphere exchange is mediated by physico-chemical and biological processes which are very sensitive to prevailing environmental conditions. Trace gas exchange, ecology, atmospheric chemistry and climate are associated with processes that operate in very different characteristic spatial and temporal scales (Fig. 3) and their incorporation provides a challenge to coupled Earth System models. In addition, many interactions may differ depending on whether a pristine or polluted environment is considered. Until recently, atmospheric chemistry-transport models (CTMs) relied on emission inventories which assumed constant seasonal or mean-annual emissions over inter-annual to decadal timescales (Prather et al., 2001; Gauss et al., 2006; Stevenson et al., 2006). Coupling CTMs to DGVMs allows the use of emissions which respond to the local climate and surface conditions at high temporal frequencies, as well as a more accurate description of dry deposition and uptake of trace gases by vegetation (Hauglustaine et al., 2005).

\subsection{DGVM model structure}

In the existing DGVMs plant photosynthesis and autotrophic respiration are simulated in relatively similar ways (e.g., based on models by Farquhar et al., 1980; Collatz et al., 1991). Leaf carbon assimilation and water loss are typically coupled as the models contain a representation of the soil water balance, whereby stomatal conductivity and photosynthesis are reduced in periods with soil moisture deficit. Autotrophic and growth respiration are subtracted from gross photosynthesis, and a set of carbon allocation rules determines plant growth. Plant establishment, growth and mortality are represented, and their response to resource availability (light, water), disturbance and climate extremes underpins simulated population dynamics. Decomposition of dead tissue is described as a function of soil carbon content, temperature and soil moisture. Typically a number of soil pools are distinguished that represent material with different residence times. Some DGVMs have begun to move towards a more detailed representation of canopy dynamics and resource competition by adopting the "gap model" concept where average individuals represent the properties of a certain age cohort of a given PFT (Moorcroft et al., 2001; Smith et al., 2001). While computationally expensive, the gap concept allows the simulation of successional dynamics, reflecting competition between light-demanding and shade-tolerant plants (Smith et al., 2001; Hickler et al., 2004; Miller et al., 2008). For more detailed review of DGVMs see (Cramer et al., 2001; Prentice et al., 2007; Sitch et al., 2008).

Coupling of the carbon and nitrogen cycles is an active area of research within the terrestrial modelling community (Sokolov et al., 2008; Xu-Ri and Prentice, 2008; Thornton et al., 2009). Many DGVMs assign fixed C:N ratios for plant tissues and assume sufficient leaf nitrogen is available for photosynthesis; only few include a coupled soil $\mathrm{C}$ and N scheme (Cramer et al., 2001; Prentice et al., 2007). DGVMs require relatively little input: climate, soil type and atmospheric $\mathrm{CO}_{2}$ concentration and can be run from (sub)daily to glacial/interglacial time scales. They have been evaluated using flask measurements of $\mathrm{CO}_{2}$ from a global network of monitoring stations, eddy covariance data of $\mathrm{CO}_{2}$ exchange, field manipulation experiments (e.g. FreeAir-Carbon Enrichment experiments), and field data on net primary productivity (NPP), biomass and soil carbon content 


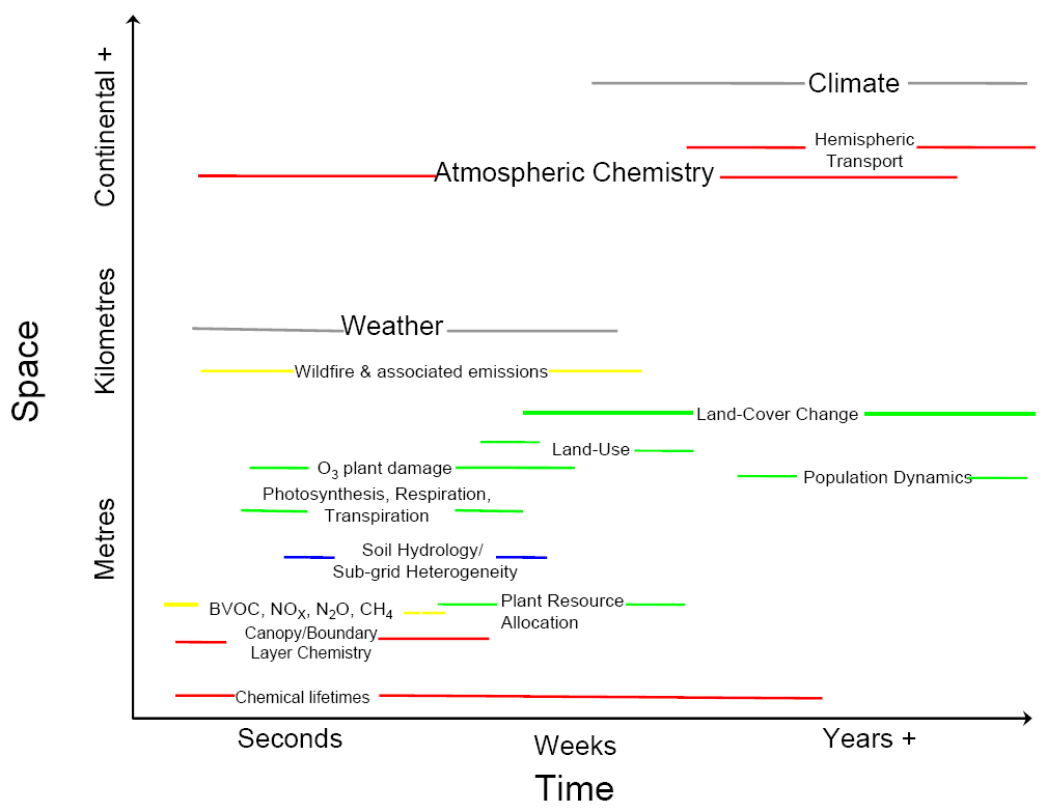

Fig. 3. Characteristic spatial and temporal scales associated with DGVMs and climate models, trace-gas biosphere-atmosphere exchange and atmospheric chemistry. Green lines: processes associated with plant physiology/land cover; yellow lines: trace gas emissions; blue: surface hydrology/energy balance; red: chemical transformations and related processes; grey: weather and climate.

(McGuire et al., 2001; Friend et al., 2007; Hickler et al., 2008).

\subsection{Inclusion of new land cover types and processes in DGVMs}

\subsubsection{Land use, land cover change and related non- $\mathrm{CO}_{2}$ trace gas emissions}

A substantial fraction of the anthropogenic emissions of non$\mathrm{CO}_{2}$ trace gas and particulate matter are due to land use and land cover change (Bruisma, 2003). Already with development of agriculture some 10000 years ago (Roberts, 1989) humans began to transform the land surface (Olofsson and Hickler, 2007). Historical land use and cover changes are important not only as a large carbon source over the last centuries (Houghton, 1999, 2003) but for pre-industrial non$\mathrm{CO}_{2}$ trace gas emissions, e.g., of BVOC and fire related emissions (Arneth et al., unpublished), and hence for preindustrial to present-day radiative forcing calculations. In the context of climate change, future land use must both supply agricultural products for a growing population (Vitousek et al., 1986), and target new ecosystem services, like soil carbon sequestration or agrofuels (Lal, 2004). Depending on the crop type and its phenology, future climate warming might be locally either advantageous (increased growing period) or detrimental (insufficient vernalization, increased water and heat stress; Lobell et al., 2008) to crop yields. Tropospheric $\mathrm{O}_{3}$ tends to reduce photosynthesis and yields (Ashmore, 2005).
Accounting for the human influence is therefore crucial for modelling terrestrial trace gas exchange and its climate effects through biophysical and biogeochemical feedbacks. In many land use simulations, agriculture is represented as grassland, by harvesting a fraction of the (natural) productivity or crop growing seasons are prescribed (e.g. McGuire et al., 2001; Feddema et al., 2005). Several studies that parameterised land surface schemes specifically for crops (Challinor et al., 2004; Kothavala et al., 2005; Osborne et al., 2007) have concentrated on short term land-atmosphere interactions. The carbon cycle is not closed, and neither the removal of carbon through harvest nor the long-term soil carbon dynamics were analysed. Recent studies (Davin et al., 2007) estimate past and future cooling due to the biophysical effects of anthropogenic land cover change, while Lobell et al. (2006) relate different cooling levels to crop management.

Biogeochemical impacts of land use and cover change within DGVMs were simulated initially by replacing forests with productive grassland or simply by harvesting a fraction of the (natural) productivity (McGuire et al., 2001). Using a suite of biogeochemical models, McGuire et al. (2001) found the opposing effects of $\mathrm{CO}_{2}$ fertilization and historical land cover changes to be the two largest factors governing changes in terrestrial carbon storage over the 20th century. Using the DGVM LPJ coupled to the CLIMBER-2 climate model, Brovkin et al. (2004) quantified the effects of historical land cover changes as a biophysical $\left(0.26^{\circ} \mathrm{C}\right)$ cooling due to an increase in northern latitude albedo which was partially offset by a biogeochemical $\left(0.18^{\circ} \mathrm{C}\right)$ warming due to atmospheric $\mathrm{CO}_{2}$ increases over the last 150 years; for future 
land cover change, simulations of the biogeochemical warming largely from tropical deforestation either dominated over the biophysical cooling or amplified the biophysical warming associated with Northern Hemisphere land abandonment, depending on the socio-economic story-line used (Sitch et al., 2005).

Local-scale crop models have been developed by agronomists since the 1970s and are increasingly being applied at larger scales, projecting an increase in production in the northern latitudes due to $\mathrm{CO}_{2}$ fertilization and warming, while production in the tropical semi-arid areas may decline due to water shortage (Rosenzweig et al., 1993; Parry et al., 1999; Reilly and Schimmelpfenning, 1999; Rosenzweig and Iglesias, 2001; Fischer et al., 2002; Tan and Shibasaki, 2003; Challinor et al., 2007). For a regional application, remote sensing information on canopy height was used to constrain carbon stocks and fluxes calculated with a heightresolved vegetation model (Hurtt et al., 2004). The output of crop models is typically restricted to yield and water requirements although their internal algorithms often include the crop canopy seasonality. Growth processes of individual crops (or crop functional types), have been implemented as an integral part of the modelling framework in three agroDGVMs which can be run globally or at the regional scale with the coexisting simulation of natural vegetation (see Table 1). Generally, progress in this area allows terrestrial biogeochemical cycle calculations to be explicitly linked with socio-economic scenarios.

In agro-DGVMs, biophysical processes, soil decomposition and some plant physiological processes (e.g. photosynthesis and respiration) are computed using the same formulations (but with adapted parameters) for crops and natural PFTs. Hence these models compute consistent land carbon and water budgets for croplands and natural ecosystems. Other parameterizations are crop-specific, such as the phenological development and carbon allocation to the different pools (e.g. the economically important yield storage organs) during the growing period. Some functions exist only for managed land, like residue processing, crop rotations or irrigation. Two different strategies to implement land-use processes in DGVMs can be distinguished. In the first the parameterizations are built in the host DGVM. For example, algorithms from the EPIC crop growth model (Williams et al., 1989) were adopted in the models Agro-IBIS (Kucharik, 2003) and LPJmL (Sitch et al., 2003; Bondeau et al., 2007). In the second, the DGVM (e.g. ORCHIDEE; Krinner et al., 2005a), is coupled to an agronomy model (e.g. STICS; Brisson et al., 2002) that provides, on a daily time step, the DGVM with all variables that are crop-specific (Gervois et al., 2004). This approach facilitates fast inclusion of any improvement in the agronomical representation.

Agro-IBIS has mainly been developed for continental US agriculture (wheat, maize, soybean), and has been intensively tested for the impacts of different management practises on soil and vegetation $\mathrm{C}$ and $\mathrm{N}$ pools, crop yields, $\mathrm{C}$ and water fluxes, and $\mathrm{N}$ leaching. It was applied to investigate crop yields and environmental problems at the river basin scale (Donner et al., 2004; Donner and Kucharik, 2003) and to quantify the various factors associated with farming practices which drive carbon fluxes (Kucharik and Twine, 2007), while Twine et al. (2004) used it to simulate the biophysical effects of land cover change from natural vegetation to crops.

The coupled ORCHIDEE-STICS model has been developed predominantly for European crops with agriculture described by three generic crop types: wheat-based functions are assumed to represent most of the winter C3-type crops, maize-based parameterizations are used for C4-type crops and soybean-based functions are used for C3-type summer crops. The model has been evaluated against water and carbon fluxes at specific sites, inter-annual yields at the European scale, and is used to simulate the impacts of historical land management on yields and carbon storage in Europe (Gervois et al., 2008) as well as to North American wheat and maize (Gervois et al., 2004).

LPJmL (Bondeau et al., 2007) defines eleven Crop Functional Types (CFTs) and one managed grass. It allows trends in global harvest, vegetation and soil carbon, NPP, water and $\mathrm{CO}_{2}$ fluxes of the actual vegetation to be simulated and the impact of land use and land cover change globally to be quantified (Bondeau et al., 2007). Zaehle et al. (2007) estimated a carbon sequestration potential of agricultural abandonment and afforestation in Europe of $17-38 \mathrm{TgC} \mathrm{a}^{-1}$ by 2100 , although this was strongly reduced or even offset by climate warming. Müller et al. (2007) produce the inverse picture on the global scale, estimating that the impacts of non-climatic factors on land-use to be as important as the direct climatic factors and $\mathrm{CO}_{2}$ fertilisation.

Simulations of the greenhouse gases $\mathrm{CH}_{4}$ and $\mathrm{N}_{2} \mathrm{O}$, or of $\mathrm{NO}_{\mathrm{x}}$, with Agro-DGVMs have not yet been attempted but it will be important to assess the impacts of land management on these emissions. In terms of $\mathrm{N}_{2} \mathrm{O}$, important initial studies have been conducted based on global data assimilation (Stehfest and Bouwman, 2006), and by modelling crop production within the ecosystem model DAYCENT (Stehfest et al., 2007) which provides a tool to simulate the impact of agricultural management on soil nitrogen dynamics and trace gas fluxes. At the regional scale, several groups have used GIS data coupled to ecosystem models to simulate GHG exchange from various land uses, e.g. for rice based agricultural systems in China (Li et al., 2004; Huang et al., 2006), or for grasslands, forests and agricultural systems in Europe or the US (Soussana et al., 2004; Kesik et al., 2005; Del Grosso et al., 2006; Butterbach-Bahl et al., 2008). The next step is to adopt such modules in agro-DGVMs and to analyse the effect of management strategies on emissions reduction, like, for instance, recommended mid-season drainage of rice paddies intended to reduce the $\mathrm{CH}_{4}$ emissions, or the use of crop residues for biofuel instead of burning. 
Table 1. Summary overview of three Agro-DGVMs.

\begin{tabular}{|c|c|c|c|c|c|c|c|}
\hline $\begin{array}{l}\text { DGVM version } \\
\text { with crops, } \\
\text { land use and } \\
\text { land cover } \\
\text { change }\end{array}$ & $\begin{array}{l}\text { Original } \\
\text { DGVM }\end{array}$ & $\begin{array}{l}\text { main variables } \\
\text { simulated }\end{array}$ & $\begin{array}{l}\text { natural PFTs } \\
\text { and crops } \\
\text { represented and } \\
\text { domain of } \\
\text { application }\end{array}$ & $\begin{array}{l}\text { model tests of } \\
\text { the crop sub- } \\
\text { module, or of } \\
\text { the combined } \\
\text { model (natural } \\
\text { vegetation + } \\
\text { agriculture) }\end{array}$ & $\begin{array}{l}\text { applications us- } \\
\text { ing the crop } \\
\text { sub-modules } \\
\text { only }\end{array}$ & $\begin{array}{l}\text { applications using } \\
\text { the land cover } \\
\text { change sub- } \\
\text { modules only (i.e. } \\
\text { using a simple land } \\
\text { use representation } \\
\text { within the original } \\
\text { DGVM ) }\end{array}$ & $\begin{array}{l}\text { applications using } \\
\text { both crop and } \\
\text { land cover change } \\
\text { sub-modules }\end{array}$ \\
\hline $\begin{array}{l}\text { Agro-IBIS } \\
\text { (Kucharik and } \\
\text { Brye, 2003) }\end{array}$ & $\begin{array}{l}\text { IBIS (Foley } \\
\text { et al., 1996) }\end{array}$ & $\begin{array}{l}\text { - energy, water, } \\
\text { carbon, and } \\
\text { momentum bal- } \\
\text { ance of } \\
\text { the soil-plant- } \\
\text { atmosphere } \\
\text { system } \\
\text { - seasonal LAI } \\
\text { - C and N } \\
\text { pools, crop } \\
\text { yields }\end{array}$ & $\begin{array}{l}8 \text { Tree PFTs, } \\
2 \text { grass PFTs, } \\
2 \text { shrubs PFTs } \\
\text { + wheat, maize, } \\
\text { soybean (crops } \\
\text { for the conti- } \\
\text { nental US) }\end{array}$ & $\begin{array}{l}\text { - seasonal } \mathrm{CO}_{2} \\
\text { and water } \\
\text { fluxes at } \\
\text { AMERI FLUX } \\
\text { eddy covari- } \\
\text { ance sites } \\
\text { - crop yields } \\
\text { and N leaching } \\
\text { within the Mis- } \\
\text { sissipi basin }\end{array}$ & $\begin{array}{l}\text { - impacts of } \\
\text { climate and } \\
\text { land use man- } \\
\text { agement on } \\
\text { crop yields } \\
\text { and nitrate } \\
\text { export (Donner } \\
\text { and Kucharik, } \\
\text { 2003; Donner } \\
\text { et al., 2004) } \\
\text { - impacts of } \\
\text { crops manage- } \\
\text { ment on NEP } \\
\text { (Kucharik and } \\
\text { Twine, 2007) }\end{array}$ & $\begin{array}{l}\text { - impact of the land } \\
\text { cover change on } \\
\text { terrestrial carbon } \\
\text { storage (McGuire } \\
\text { et al., 2001) }\end{array}$ & $\begin{array}{l}\text { - impact of land } \\
\text { use on the energy } \\
\text { and water balance } \\
\text { (Twine et al., 2004) }\end{array}$ \\
\hline $\begin{array}{l}\text { ORCHIDEE- } \\
\text { STICS } \\
\text { (Gervois et al., } \\
\text { 2004; de } \\
\text { Noblet- } \\
\text { Ducoudré } \\
\text { et al., 2004) }\end{array}$ & $\begin{array}{l}\text { ORCHIDEE } \\
\text { (Krinner et } \\
\text { al., 2005b) }\end{array}$ & $\begin{array}{l}\text { - energy, water, } \\
\text { carbon, and } \\
\text { momentum bal- } \\
\text { ance of } \\
\text { the soil-plant- } \\
\text { atmosphere } \\
\text { system } \\
\text { - seasonal LAI } \\
\text { - C and N } \\
\text { pools, crop } \\
\text { yields }\end{array}$ & $\begin{array}{l}7 \text { Woody PFTs } \\
+2 \text { grass PFTs } \\
+ \text { wheat, maize } \\
\text { and soybean } \\
\text { (European } \\
\text { crops that } \\
\text { have also been } \\
\text { shown to be } \\
\text { valid for the } \\
\text { US) }\end{array}$ & $\begin{array}{l}- \text { seasonal } \\
\mathrm{CO}_{2} \text { and water } \\
\text { fluxes at eddy } \\
\text { covariance flux } \\
\text { sites } \\
\text { - national crop } \\
\text { yields statistics } \\
\text { - seasonal and } \\
\text { interannual } \\
\text { variability of } \\
\text { LAI } \\
\text { - comparison } \\
\text { against } \mathrm{CO}_{2} \\
\text { fluxes from } \\
\text { atmospheric } \\
\text { measurements }\end{array}$ & & $\begin{array}{l}\text { - impact of his- } \\
\text { torical land cover } \\
\text { change on climate } \\
\text { (Davin et al., 2007) }\end{array}$ & $\begin{array}{l}\text { - impacts of crop- } \\
\text { lands on the Eu- } \\
\text { ropean carbon and } \\
\text { water budget (de } \\
\text { Noblet-Ducoudré } \\
\text { et al., 2004) } \\
\text { - historical impacts } \\
\text { of management on } \\
\text { yield and carbon } \\
\text { storage (Gervois et } \\
\text { al., 2008) }\end{array}$ \\
\hline $\begin{array}{l}\text { LPJmL } \\
\text { (Bondeau et al., } \\
2007 \text { ) }\end{array}$ & $\begin{array}{l}\text { LPJ (Sitch } \\
\text { et al., 2003) }\end{array}$ & $\begin{array}{l}\text { - water and car- } \\
\text { bon fluxes of } \\
\text { the } \\
\text { soil-plant- } \\
\text { atmosphere } \\
\text { system } \\
\text { - seasonal LAI } \\
\text { - C pools, crop } \\
\text { yields }\end{array}$ & $\begin{array}{l}7 \text { tree PFTs + } \\
2 \text { grass PFTs + } \\
\text { temperate } \\
\text { and tropical } \\
\text { cereals, rice, } \\
\text { maize, temper- } \\
\text { ate and tropical } \\
\text { roots, pulses, } \\
\text { sunflowers, } \\
\text { groundnuts, } \\
\text { rapeseed, } \\
\text { grazed or } \\
\text { harvested } \\
\text { grassland } \\
\text { (global) }\end{array}$ & $\begin{array}{l}\text { - seasonal } \mathrm{CO}_{2} \\
\text { fluxes at eddy } \\
\text { covariance flux } \\
\text { sites } \\
\text { - seasonal } \\
\text { simulated fPAR } \\
\text { against satellite } \\
\text { derived fPAR } \\
\text { (globally) } \\
\text { - national crops } \\
\text { yields statistics } \\
\text { for wheat and } \\
\text { maize } \\
\text { - changes in } \\
\text { Soil carbon } \\
\text { related to land } \\
\text { use changes }\end{array}$ & $\begin{array}{l}\text { - comparative } \\
\text { impacts of } \\
\text { climatic and } \\
\text { non-climatic } \\
\text { factors on } \\
\text { global biogeo- } \\
\text { chemical cycles } \\
\text { (Muller et al., } \\
\text { 2006) } \\
\text { - land use } \\
\text { and water use } \\
\text { modelling } \\
\text { (Lotze-Campen } \\
\text { et al., 2005) } \\
\text { - bottom-up } \\
\text { modelling of } \\
\text { the NEP } \\
\text { anomaly due to } \\
\text { the European } \\
\text { 2003 heat wave } \\
\text { (Vetter et al., } \\
\text { 2008; Jung et } \\
\text { al., 2008) }\end{array}$ & $\begin{array}{l}\text { - impact of the } \\
\text { land cover change } \\
\text { effects on the ter- } \\
\text { restrial carbon stor- } \\
\text { age (McGuire et al., } \\
2001 \text { ) } \\
\text { - historical and } \\
\text { future land cover } \\
\text { change impact (bio- } \\
\text { physical effects and } \\
\mathrm{CO}_{2} \text { increase) on } \\
\text { climate (Brovkin et } \\
\text { al., 2004;Sitch et } \\
\text { al., 2005) }\end{array}$ & $\begin{array}{l}\text { - impact of his- } \\
\text { torical land cover } \\
\text { change on green } \\
\text { water flow (Gerten } \\
\text { et al., 2005) } \\
\text { - European vulner- } \\
\text { ability to climate } \\
\text { change (Schröter et } \\
\text { al., 2005) } \\
\text { - historical impacts } \\
\text { of agriculture on } \\
\text { the terrestrial car- } \\
\text { bon balance (Bon- } \\
\text { deau et al., 2007) } \\
\text { - estimated impacts } \\
\text { of agriculture on } \\
\text { the European and } \\
\text { global carbon bal- } \\
\text { ance for the } 21 \text { trh } \\
\text { century (Zaehle et } \\
\text { al., 2007; Muller et } \\
\text { al., 2007) } \\
\text { - agricultural water } \\
\text { consumption \& re- } \\
\text { lated issues (Rost et } \\
\text { al., 2008) }\end{array}$ \\
\hline
\end{tabular}




\subsubsection{Wetlands and methane emissions}

$\mathrm{CH}_{4}$ emissions from wetlands are known to be highly dependent on water table position, temperature and availability of carbonaceous substrate (Walter et al., 2001). This dependence can be seen at both the small (Roulet et al., 1992; Christensen et al., 2003) and the large scale (Bousquet et al., 2006). Similar to natural wetlands, emissions from rice agriculture are also strongly dependent on temperature (Khalil et al., 1989) and water table as defined by irrigation patterns. Drainage of wetlands leads to a shift to more $\mathrm{CO}_{2}$ instead of $\mathrm{CH}_{4}$ emissions, whereas restoration will increase $\mathrm{CH}_{4}$ emissions.

Global estimates of present day $\mathrm{CH}_{4}$ emissions from wetlands are derived either by using process-based models (bottom-up approach, e.g., Cao et al., 1996; Christensen et al., 1996; Walter et al., 2001; Zhuang et al., 2004) or inverse models (top-down approach, e.g. Fung et al., 1991; Mikaloff Fletcher et al., 2004a; Wang et al., 2004; Chen and Prinn, 2006). A large source of uncertainty is in the wetland distribution itself as most processed-based models rely on timeinvariant maps of wetland extent. Some process-based models use simplistic empirical relationships between water table depth and $\mathrm{CH}_{4}$ oxidation rates and do not represent the different $\mathrm{CH}_{4}$ transport pathways (Cao et al., 1996; Gedney et al., 2004). The widely adopted approach of Walter et al. (2001) is based on soil temperature, NPP and the amount of available substrate, and water-table (derived from a simple hydrological scheme) to model emissions. Recent studies (Wania et al., 2010) include a $\mathrm{CH}_{4}$ emission model coupled directly into the DGVM to simulate the interactions between vegetation composition, soil temperature, and water table position. This approach has the advantage of modelling interactions between hydrology, vegetation and permafrost, which have not been included previously (Cao et al., 1996; Walter et al., 2001).

Methane models are evaluated using site-specific observations from chamber measurements or flux towers. Influential environmental conditions such as water table position, soil temperature or net primary production at the chamber sites can be readily determined for a small sample area and compared to model output. Chamber measurements have the disadvantage of not always including $\mathrm{CH}_{4}$ emissions via ebullition, as these highly irregular emissions are often excluded from data sets. Eddy-covariance flux measurements integrate over diffusion, plant-mediated transport and ebullition (Rinne et al., 2007) in an often heterogeneous flux footprint that consist of hummocks, hollows and lawns representing very different micro-habitats (Saarnio et al., 1997). In general, DGVMs do not simulate such spatial heterogeneity given their spatial resolution of typically 0.5 to 1 degrees. However, DGVMs can be run for individual sites or different micro-topographic features. By doing so, they can be used as a tool to explore the impact of small-scale spatial heterogeneity on the simulation of large scale fluxes. Inverse modelling techniques can help to constrain the process-based models at the regional and global scales. Important limitations arise from lack of suitable observations and uncertainty in the sink terms, e.g. seen in the large spread in estimates of global wetland $\mathrm{CH}_{4}$ emissions using this approach, 145-231 Tg CH $\mathrm{CH}_{4} \mathrm{a}^{-1}$ (Forster et al., 2007). Satellite measurements of total column $\mathrm{CH}_{4}$ have also recently become available (Buchwitz et al., 2005; Frankenberg et al., 2005) and developments in inversion techniques have included using isotopic $\mathrm{CH}_{4}$ data (Mikaloff Fletcher et al., 2004a). Isotopes of carbon $\left({ }^{13} \mathrm{C}\right)$ and hydrogen (deuterium) can help to localise methane sources, but are yet to be included in a global, process-based methane model.

Simulations of past $\mathrm{CH}_{4}$ emissions are even more data limited, especially in the distribution and extent of wetlands for the last glacial maximum and during deglaciation (Kaplan, 2002; Valdes et al., 2005). The inter-hemispheric gradient in atmospheric methane levels derived from ice cores can help locate methane sources in the past. Future wetland emissions will depend on warming, directly elevating emission rates and indirectly via changes in the distribution of wetlands (Cao et al., 1998; Gedney et al., 2004; Zhuang et al., 2004). Zhuang et al. (2004) estimate that high latitude emissions have increased over the 20th century and Gedney et al. (2004) predict an approximate doubling of wetlands emissions over the 21 st century under the IS92A scenario.

Future climate warming is projected to be most pronounced over high latitudes, regions where frozen soils are prevalent; especially sensitive are frozen soils that currently exist near the freezing point of water. The spatial and temporal dynamics of permafrost and periodic disturbance are crucial in shaping high-latitude landscapes, with important consequences for the spatial extent of wetlands and the exchange of $\mathrm{CO}_{2}$ and $\mathrm{CH}_{4}$. There is increasing evidence that these changes are already occurring across large portions of the Arctic (Serreze et al., 2002; Hinzman et al., 2005). The active layer depth in permafrost areas is likely to change dramatically over the next century (Lawrence and Slater, 2005; Euskirchen et al., 2006; Zhang et al., 2008), thus changing local drainage patterns. The thawing of permafrost could lead to better local drainage leading to drier conditions and therefore reduced $\mathrm{CH}_{4}$ emissions, but if drainage is impeded, it may lead to enhanced inundation and wetter and warmer conditions favouring higher $\mathrm{CH}_{4}$ emissions (Christensen et al., 2004). Permafrost and active-layer dynamics are now being developed and incorporated into DGVMs (Venevsky, 2001; Zhuang et al., 2003; Beer et al., 2007; Wania et al. 2009), and used to investigate the relationship between permafrost degradation, wetland-forest carbon dynamics, trace gas emissions and wildfire. 


\subsubsection{Nitrogen exchange in natural and agricultural ecosystems}

Several processes govern the flow of nitrogen through terrestrial ecosystems, including nitrogen fixation; uptake by organisms; immobilisation (assimilation of nitrogen into plant and microbial tissue) and mineralisation (decomposition of soil organic matter to $\mathrm{NH}_{4}^{+}$); nitrification (biological oxidation of $\mathrm{NH}_{4}^{+}$to $\mathrm{NO}_{2}^{-}$and $\mathrm{NO}_{3}^{-}$), denitrification (biological reduction of $\mathrm{NO}_{3}^{-}$and $\mathrm{NO}_{2}^{-}$to gaseous $\mathrm{N}$ ), and the perturbation of the natural cycle by anthropogenic nitrogen deposition, and leaching of excess nitrate into groundwater. The division of nitrogen between soil organic matter $(\mathrm{C}: \mathrm{N} \sim 15)$ and plant biomass $(\mathrm{C}: \mathrm{N} \sim 200)$ together with the total land $\mathrm{N}$ budget and the degree to which plants can alter their C:N ratios will critically determine the ability of terrestrial ecosystems to sequester anthropogenic $\mathrm{CO}_{2}$ in the future (Finzi et al., 2007; Thornton et al., 2007; Gruber and Galloway, 2008). However all of these processes are associated with large uncertainties (Holland et al., 1999; Prentice et al., 2000; Dentener et al., 2006b). A major uncertainty with regard to the $\mathrm{N}$ cycle, the quantification of $\mathrm{N}_{2}$ denitrification losses on site to regional scales, remains an unsolved challenge (Groffman et al., 2009).

At the site scale, a range of process-oriented models with widely varying approaches and degree of detail (Boyer et al., 2006) have been applied with mixed success in natural, semi natural and managed ecosystems to simulate nitrificationdenitrification related trace gas emissions. The physicochemical and biological factors driving nitrification and denitrification depend strongly on microsite conditions. This poses a major challenge for modelling the temporal dynamic of nitrogen trace gas exchange, and more generally for all redox-sensitive sources (e.g. $\mathrm{CH}_{4}$ emission versus oxidation) since aerobic and anaerobic zones in soils determine whether oxidative processes (such as nitrification) or reductive processes (such as denitrification) dominate. Simulation of nitrogen oxide fluxes is further complicated by the need to account for the diffusion resistance of soil and canopy and, for $\mathrm{NO}_{\mathrm{x}}$, chemical reactions within the canopy that can alter the net flux from the soil surface by up to $50 \%$ (Ganzeveld et al., 2002a). Single column canopy transfer schemes for $\mathrm{NO}_{\mathrm{x}}$ do exist, however, they are yet to be used in conjunction with ecosystem models to simulate nitrogen gas exchanges (Ganzeveld et al., 2002b).

Plot-scale models have been linked to regional databases on soil, land-use and climate to simulate emissions for boreal, temperate and wet tropical forests (e.g., Kesik et al., 2005; Werner et al., 2007), as well as for agriculturally dominated landscapes (Butterbach-Bahl et al., 2004; Gabrielle et al., 2006). However, these upscaling experiments rely heavily on the availability and quality of data on soil physical properties (e.g., Batjes, 2002) and initial conditions for soil and vegetation carbon and nitrogen stocks for model initiali- sation and parameterisation. The latter requirement suggests the potential usefulness of coupling site-scale emission models into DGVMs that provide spatially explicit information corresponding to local climate and pedographic conditions (see for example, Werner et al., 2007).

Several regional and global studies simulated source emissions of $\mathrm{NO}_{\mathrm{x}}, \mathrm{N}_{2} \mathrm{O}$ (Potter et al., 1996; Potter and Klooster, 1998; Parton et al., 2001) and $\mathrm{NH}_{3}$ (Potter et al., 2003) from soils that were based on process descriptions combined with remote sensing information and vegetation models. At the scale of DGVMs modelling of nitrogen trace gas emissions is still at a very early stage. In general a common structure is applied: $\mathrm{N}$ affects gross photosynthesis, transpiration and autotrophic respiration (Field and Mooney, 1986; Sprugel et al., 1995). N availability to plants thereby controls leaf area and plant growth, with the formation of new tissue being subject to plant specific C:N ratios. Plants retain a fraction of leaf $\mathrm{N}$ on leaf abscission and thereby influence the quality of litter entering the soil. This $\mathrm{N}$-dependent quality impacts on the decomposability of fresh litter (Anderson, 1973; Jansens and Luyssaert, 2009). Decomposition of organic matter results in sequestration or release of mineral nitrogen, depending on the $\mathrm{C}: \mathrm{N}$ ratio of the decomposing material and the $\mathrm{N}$ requirements for the growth of soil microbes. Mineral $\mathrm{N}$ dynamics usually account for nutrient competition between soil microbes and plants, and processes of leaching to groundwater, including some protection against leaching resulting from adsorption to clay minerals, and a generic loss term to denitrification dependent on mineral N (e.g. Friend et al., 1997; Thornton et al., 2002). Dickinson et al. (2002) go further by simulating nitrification and denitrification processes as a function of $\mathrm{N}$ availability and soil moisture, however, they represent gaseous losses from these processes in a lumped manner.

Recently, algorithms that are based on the adaptation of process-based emission models at the site scale (e.g. DNDC; Li et al., 2000) have been adopted for use in DGVMs (Xu-Ri and Prentice, 2008; Zaehle and Friend, 2009). Taking advantage of the "closed" and consistent $\mathrm{N}$ cycle formulation of the DGVMs, these approaches tightly couple the terrestrial $\mathrm{C}$ and $\mathrm{N}$ cycles, and the process representation of $\mathrm{N}$ trace gas production and emissions apply (e.g., an empirically derived split of the soil in aerobic and anaerobic fractions). First model integrations have shown global flux estimates to be within the range of observation based estimates (Xu-Ri and Prentice, 2008; Zaehle and Friend, 2009).

Data on nitrogen trace gas fluxes are still scarce (Stehfest and Bouwman, 2006) and often not all information required to correctly interpret these measurements are available. Fluxes are remarkably variable in response to environmental conditions, vegetation type and management practices and despite recent advances in data availability, these differences are not yet fully understood (Schindlbacher et al., 2004). Site-scale observations of $\mathrm{NO}_{\mathrm{x}}$ and $\mathrm{N}_{2} \mathrm{O}$ soil emissions are biased towards short-term studies in 
temperate/boreal croplands, pastures and forests while information from tropical and particular semi-arid and seasonally wet regions is in view of the global importance of this biome types still scarce (e.g. Martin et al., 2003; Brummer et al., 2008). Using space-based observations, Jaegle et al. (2004) have recently suggested that soil $\mathrm{NO}_{\mathrm{x}}$ emissions from semiarid regions are significantly contributing to $\mathrm{O}_{3}$ enhancement in tropical Africa. A major challenge towards providing a critical benchmark for global scale nitrogen trace gas modelling is the compilation of observations into regional databases, such as in Pilegaard et al. (2006), and in validating and applying space-based observations, as those derived from GOME or Schiamachy.

$\mathrm{N}_{2} \mathrm{O}$ concentration observed at atmospheric stations can be exploited to evaluate the simulated seasonality of net landatmosphere $\mathrm{N}_{2} \mathrm{O}$ fluxes using CTMs. These measurements can then be used in inversion studies to attribute variations in atmospheric concentrations to sinks and sources according to latitudinal bands and terrestrial versus marine origin, which could provide an integrative benchmark of simulated $\mathrm{N}_{2} \mathrm{O}$ fluxes (Hirsch et al., 2006). Large uncertainty exists in such inverse estimates, because the assumed prior net $\mathrm{N}_{2} \mathrm{O}$ flux is highly uncertain, but potentially important for the inferred outcome (Hirsch et al., 2006). Also, the atmospheric transport itself contributes substantially to the observed seasonal cycle of $\mathrm{N}_{2} \mathrm{O}$ concentrations (Nevison et al., 2007). CTMs can in principle be also used to evaluate emission of $\mathrm{NO}_{\mathrm{x}}$ by transporting simulated emissions to stations with observed nitrogen deposition. However, $\mathrm{N}$ deposition estimates from the current generation of CTMs driven with similar emission fields differ considerably because of differences in the representation of $\mathrm{NO}_{\mathrm{x}}$ chemistry and deposition processes (Dentener et al., 2006b). The potential to use atmospheric data for the evaluation of large-scale $\mathrm{NH}_{\mathrm{x}}$ emission modelling is very limited because of the short lifetime of $\mathrm{NH}_{\mathrm{X}}$ in the atmosphere.

First attempts to study climate change feedbacks suggest $\mathrm{NO}$ emissions from forest soils in Europe may increase by $9 \%$, whereas $\mathrm{N}_{2} \mathrm{O}$ emissions may decrease by $6 \%$ due to predicted changes in temperature and rainfall for the 2030s (Kesik et al., 2006). Land management dominates site to globalscale $\mathrm{N}$ trace gas fluxes. Representing land use in DGVMs (see Sect. 3.2.1) is therefore crucial for modelling $\mathrm{N}$ trace gas emissions. Fertilizer application to arable land and pastures have been identified as main drivers of $\mathrm{N}$ trace gas emissions, owing to its significant effect on site $\mathrm{N}$ availability (Forster et al., 2007). Recently Crutzen et al. (2008) estimated that the loss of $\mathrm{N}_{2} \mathrm{O}$ from reactive nitrogen (via e.g. fertilization, $\mathrm{N}$ deposition, and indirect emissions in the course of cascading) is in the range of $3-5 \%$ rather than $2 \%$ as used in the IPCC guidelines. This has implications for any land use change from natural towards managed systems and also affects our view on benefits which may possibly be achieved by implementing large scale bioenergy production systems as a measure for climate protection. Furthermore, conversion of natural systems into pasture or arable systems in tropical regions or the drainage of wetlands for forestry or agriculture have been shown to result in the mobilisation of soil $\mathrm{C}$ and $\mathrm{N}$ stocks accompanied by pulses of $\mathrm{N}$ trace gas emissions lasting up to several years (e.g., Melillo et al., 2001; Smith and Conen, 2004). Even the change from till towards notill agricultural systems may promote $\mathrm{N}_{2} \mathrm{O}$ emissions due to the alteration of the $\mathrm{C}$ and $\mathrm{N}$ cycles (Six et al., 2004; Li et al., 2005). Further studies with fully coupled vegetation, climate, hydrology and soil biogeochemical models are needed to gain a comprehensive understanding of possible feedbacks of $\mathrm{N}$ trace gas exchange due to global change.

\subsubsection{Fire and fire-related emissions}

Fire-related trace gas emissions are estimated using global/regional emission models or global, process-based fire models embedded in DGVMs (Table 2). Emission models combine remote sensing products, databases and inventories to prescribe area burnt, and to estimate fuel loads in order to predict trace gas emissions. Process-based fire models represent fire initiation, spread and effects. Climate data and ecosystem variables governing fuel load and status (provided by the DGVM) serve as input. Model outputs include area and biomass burnt and associated changes in the simulated carbon pools of vegetation and litter. $\mathrm{CO}_{2}$ emissions are therefore driven by area burnt, fuel load and fuel consumption. Both groups of fire models rely on biome-specific emission factors (EF) to estimate trace gas emissions. However, the conditions that determine the ratio between flaming and smouldering combustion which determines non- $\mathrm{CO}_{2}$ trace gas emissions is fixed (Andreae and Merlet, 2001).

Emission models show the influence of extreme fire events and ENSO (van der Werf et al., 2004, 2006) on GHG fluxes to the atmosphere. However, they are limited by the available data-base or satellite information and rely on prescribed assumptions about fire behaviour (surface vs. crown fires) and combustion efficiencies. With improving quantity and quality, remote-sensing products are able to capture real time, continuous global coverage but uncertainties remain regarding reliable products to estimate area burnt, fuel load (driven by vegetation productivity) and land cover (vegetation type, natural vs. non-natural). Fire Radiative Power is a novel development, where the energy content of a fire is detected from remote-sensing fire products and can help to distinguish surface from crown fires and possibly combustion completeness (Wooster et al., 2005).

Process-based fire models in DGVMs try to capture the bi-directional feedbacks between fire frequency, fire effects and vegetation dynamics. Implementation of fire behaviour and intensity within DGVMs, e.g. the SPITFIRE model (SPread and InTensity of FIRE; Thonicke et al., 2009) in the LPJ-DGVM, provide the basis to simulate trace gas emissions. SPITFIRE explicitly accounts for both lightning- and human-caused ignitions. Fire spread only takes place when 
Table 2. Comparison of emission and process-based fire models.

\begin{tabular}{lll}
\hline & $\begin{array}{l}\text { Emission models: GWEM } \\
\text { (Hoelzemann et al., 2004), } \\
\text { GFEDv2 (van der Werf et } \\
\text { al., 2004), BWEM (Kasischke } \\
\text { et al., 2005) }\end{array}$ & $\begin{array}{l}\text { Process-based Fire-DGVM: } \\
\text { MCFire (Lenihan and Neilson, } \\
\text { 1998), SPITFIRE (Thonicke } \\
\text { et al., 2009) SEVER-FIRE } \\
\text { (Venevsky et al., unpublished) }\end{array}$ \\
\hline Area burnt & Remote sensing fire product & $\begin{array}{l}\text { Simulation of fire initiation and } \\
\text { spread }\end{array}$ \\
$\begin{array}{l}\text { Representation } \\
\text { of Vegetation }\end{array}$ & $\begin{array}{l}\text { Actual land cover with varying } \\
\text { sensitivity of LC-product used }\end{array}$ & $\begin{array}{l}\text { Potential natural vegetation } \\
\text { Integration with crop and land }\end{array}$ \\
& & use envisaged \\
$\begin{array}{l}\text { Combustion } \\
\text { efficiency }\end{array}$ & $\begin{array}{l}\text { Static combustion efficiency } \\
\text { and ratio between crown and } \\
\text { surface fire in a biome }\end{array}$ & $\begin{array}{l}\text { Simulating fire behaviour and } \\
\text { resulting fuel consumption }\end{array}$ \\
$\begin{array}{l}\text { Model } \\
\text { Application }\end{array}$ & $\begin{array}{l}\text { Limited by years with available } \\
\text { satellite observations }\end{array}$ & $\begin{array}{l}\text { Prognostics for different } \\
\text { climate conditions }\end{array}$ \\
\hline
\end{tabular}

atmospheric conditions are sufficiently dry, a state estimated using the Nesterov Index (Nesterov, 1949), and calculations follow Rothermel's fire spread model (Rothermel, 1972; Wilson, 1982; Pyne, 1995). Surface fire intensity is explicitly simulated. Ignitions which do not generate a sufficiently intense fire do not lead to fire spread. Tree mortality from either crown scorch (Johnson, 1992; Dickinson and Johnson, 2001) or cambial death (e.g., Stephens and Finney, 2002; Rigolot, 2004), the two most important causes for post-fire mortality, are calculated. Process-based fire models can be applied to investigate past, present and future changes in fire and vegetation-fire interactions, e.g. to quantify the contribution of biomass burning to trace gas emission during glacialinterglacial changes (Thonicke et al., 2005; Fischer et al., 2008). Most DGVMs simulate potential natural vegetation under current climate conditions, and estimates of trace gas emissions do not yet capture global fire regimes as determined by actual vegetation cover. An advance will be to incorporate fire models into agro-DGVMs.

Future global fire models will include algorithms to link burning conditions with trace gas emissions, allowing emission factors to reflect conditions, such as the ratio of grass to total litter, fuel moisture, and fire intensity (Hély et al., 2003). Experimental data from controlled burn studies and fire products from remote-sensing, i.e. fire radiative power, are becoming available to evaluate model algorithms of fuel combustion and related trace gas emissions. Process-based global fire models need to reduce uncertainties in quantifying ignitions, especially human-caused fire ignitions, also during past centuries to allow prognostic simulations to estimate changes in human use of fire since pre-historic times. Models of lightning are needed and are especially important in palaeo-climate applications, where changes in convection and lightning should be consistent with changes in climate. Here fire modellers can benefit from parameterizations in CTMs, which often include a module for $\mathrm{NO}_{\mathrm{x}}$ production by lightning; such modules calculate the number of lightning flashes, and the proportion that strike the ground (Meijer et al., 2001; Schumann and Huntrieser, 2007). Limitations of process-based fire models can be reduced further by considering agricultural and woodfuel burning in DGVMs. Fire models needs to be closely linked to ecosystem models, which provide estimates of combustible biomass $\mathrm{N}$ (see Sect. 3.2.3). Furthermore, effects of biomass burning on the magnitude and temporal pattern of soil $\mathrm{N}$ trace gas emissions (Weitz et al., 1998; Neff et al., 1995), e.g. via changes in energy and water fluxes, $\mathrm{N}$ volatilization by pyro-denitrification or changes in soil physical properties need to be taken into account.

\subsubsection{Hydrogen}

Models of the molecular hydrogen cycle have primarily focused on source and sink magnitudes, and the latitudinal distribution and seasonality of atmospheric $\mathrm{H}_{2}$ concentrations. Unlike many anthropogenically emitted gases, $\mathrm{H}_{2}$ has higher concentrations in the southern than Northern Hemisphere, which seems to arise from the strong soil uptake. Hauglustaine and Ehhalt (2002) were the first to use a CTM (MOZART) to reproduce latitudinal and seasonal gradients in $\mathrm{H}_{2}$ concentration. They assumed similar seasonality in surface $\mathrm{H}_{2}$ sources as for other compounds, for instance both anthropogenic emissions and biomass burning sources of $\mathrm{H}_{2}$ were scaled to the seasonal cycle of $\mathrm{CO}$. For $\mathrm{H}_{2}$ sinks, the 
seasonality and geographic distribution of the deposition velocity was scaled to Net Primary Productivity. While the observed latitudinal gradient in the Southern Hemisphere and tropics were reproduced in this experiment, data-model mismatches with increasing latitude, especially in the Northern Hemisphere and over the continents suggested that use of NPP for estimating uptake was inaccurate.

Two subsequent studies improved estimates of the velocity deposition by adding temperature dependencies based on observations (Yonemura et al., 2000; Smith-Downey et al., 2006). STOCHEM-CTM was applied using deposition velocities dependent on PFT and soil moisture (Sanderson et al., 2003b), and the GEOS-chem CTM with $\mathrm{H}_{2}$ uptake inhibited over snow and desert regions (Price et al., 2007). Both studies simulated improved seasonal cycles of $\mathrm{H}_{2}$ concentration in the Northern Hemisphere and improved latitudinal gradients. Neither model, however, includes a mechanistic treatment of $\mathrm{H}_{2}$ uptake. The use of a diffusion approach as presented by Smith-Downey et al. (2006), or other diffusion approaches, in a DGVM is an exciting way forward.

\subsection{Advances in modelling plant physiology}

\subsubsection{BVOC}

The vast majority of regional and global BVOC emission studies to date have concentrated on isoprene and monoterpenes, largely because these represent a significant proportion of the total $\mathrm{C}$ emitted annually in the form of BVOC (Guenther et al., 1995). Also leaf measurements on a sufficiently wide range of plants (Kesselmeier and Staudt, 1999) have allowed the development of generalised emission algorithms. Emission models typically specify the emission capacity of a leaf under standardised conditions (arbitrarily chosen to be $30^{\circ} \mathrm{C}$ and $1000 \mu \mathrm{mol} \mathrm{m}{ }^{-2} \mathrm{~s}^{-1}$ of photosynthetically active radiation). The widely observed short-term response of leaf emissions to temperature and quantum flux is then used as the basis to simulate response of emissions to weather and climate. For isoprene, current algorithms account for the hyperbolic increase in emissions with radiation flux intensity (Guenther et al., 1991, 1993), reflecting its production in the chloroplast (Lichtenthaler et al., 1997). The temperature response of isoprene is based on a modified $\mathrm{Ar}$ rhenius relationship with a maximum emission at ca. $40^{\circ} \mathrm{C}$. Monoterpenes were originally thought to be all released from storage in the leaf (e.g., specialised storage organs like resin ducts, hairs, or in the cytosol) and the emissions described in terms of a simple exponential function of temperature (Guenther et al., 1991, 1993). However, increasing evidence has emerged that many broadleaf deciduous species that produce monoterpenes do so without storing them, with concurrent emissions in an "isoprene-like" fashion (Staudt and Seufert, 1995; Kesselmeier and Staudt, 1999).

The "Guenther et al. (1993, 1995)" algorithms have been used in a range of global emission studies, and implemented in a number of DGVMs, although often with static, prescribed vegetation; an overview is presented in Arneth et al. (2008a). An alternative approach couples isoprene emissions to the electron transport rate in the leaf, based on metabolic principles (Niinemets et al., 1999; Arneth et al., 2007b). The model by Arneth et al. (2007b) accounts for a direct $\mathrm{CO}_{2}$-isoprene interaction, as found in a range of species where leaf-level emissions increase in plants grown in below ambient $\mathrm{CO}_{2}$ concentrations and a decrease at higher $\mathrm{CO}_{2}$ levels - an overview is provided in (Young et al., 2009). Using a simple function that links $\mathrm{CO}_{2}$-isoprene inhibition to changes in $C_{i}$ (Arneth et al., 2007a) successfully reproduced the available leaf observations. This result provides indirect evidence for substrate competition as the mechanism behind the $\mathrm{CO}_{2}$ effects (Rosenstiel et al., 2003), however a full mechanistic understanding of the $\mathrm{CO}_{2}$-response is still lacking. In addition, the $\mathrm{CO}_{2}$-response of emissions may help to explain the short-term decoupling that is often observed between photosynthesis and isoprene emission under conditions of soil water deficit (Pegoraro et al., 2005). The shape of the short-term vs. long-term of isoprene emissions has not yet been resolved yet and it is unclear whether the former would also be applicable for the latter (Wilkinson et al., 2009).

Plant species differ greatly in their capacity to emit isoprene and/or monoterpenes, and a major challenge for modelling global BVOC emissions in the context of DGVMs is the need to specify average standard emission capacities on the PFT level. Although emission capacities are normally adopted from Guenther et al. (1995), values chosen for individual PFTs can vary greatly among DGVMs (Arneth et al., 2008a). Using DGVMs which adopt the gap model concept can help resolve this problem in regions where PFTs can be described to represent individual tree species, for example, in mid to high latitude ecosystems (Arneth et al., 2008b). To date, isoprene estimates vary between ca. 400 and $600 \mathrm{TgCa}^{-1}$. With exception of one study (Schurgers et al., 2009), current global monoterpene estimates are uniformly based on a temperature-dependence of emissions only and have yet to account for the increasing evidence that broadleaf deciduous species tend not to store the produced monoterpenes. The variation in estimates of monoterpene emissions is ca. $30-130 \mathrm{TgC} \mathrm{a}^{-1}$, much larger than for isoprene (Arneth et al., 2008a). Model evaluation is difficult since large-scale observational constraints do not exist. Emission estimates based on top-down inversion modelling of satellite formaldehyde retrievals in combination with atmospheric chemistry models are promising, however, suffer at present from large uncertainties in the satellite information retrievals and associated with the chemical reaction pathways (e.g. Palmer et al., 2003). Canopy flux measurements may provide a means to investigate model performance locally (Arneth et al., 2007a; Schurgers et al., 2009). Isoprene and monoterpene emissions have been projected to greatly increase in the future and to have been much lower in past environments, a combination 
of the temperature response of emissions and the $\mathrm{CO}_{2}$ fertilisation effect on vegetation productivity (Guenther et al., 2006, Lathière et al., 2006). The additional, direct $\mathrm{CO}_{2}$ response results in more conservative global estimates of isoprene emissions for simulations from the last glacial maximum and into the future due to the counteracting effects of $\mathrm{CO}_{2}$-inhibition and temperature stimulation of leaf emissions in such scenarios (Arneth et al., 2007a; Heald et al., 2009).

A number of additional processes need to be accounted for in global BVOC emission models. The capacity of growing leaves to emit isoprene lags development of photosynthesis, with the lag being in cool growth environments (Wiberley et al., 2005). As a consequence, emission capacities vary as leaves age. Leaf emission capacities adapt also to the growth environment, observable in differences between sunlit and shaded leaves, and in a relatively rapid leaf response to short term weather history (Guenther et al., 2006). The latter is crucial if it suggests a tendency to acclimate emission factors in response to climate change (Guenther et al., 2006). Although most current BVOC-enabled DGVMs begin to incorporate at least some of these effects (Arneth et al., 2008a), their parameterisations are as yet empirical and associated with large uncertainty. While these processes have been mostly identified for isoprene they are likely to affect monoterpene emissions as well.

BVOCs contribute to the ubiquitous role of VOCs in atmospheric chemistry and climate due to their reactions involving $\mathrm{OH}, \mathrm{O}_{3}$ and $\mathrm{NO}_{\mathrm{x}}$ that affect lifetime and concentration of GHGs and SOA. BVOC also have a critical role for ecosystem functioning, as floral scents and as substances that protect leaves from herbivory or oxidative stress. Consequently, global emission estimates must account for substances other than isoprene and monoterpenes. In DGVMs, this has been attempted by adopting the Guenther et al. (1995) monoterpene algorithms for other groups of compounds, for example oxygenated BVOC (Lathière et al., 2006). However the approaches are oversimplified, the required observations to assign emission capacities, and crucial process understanding are missing, particularly for the possibly large emissions of induced BVOC. A recent synthesis of data on sesquiterpene emissions, a group of compounds that are very efficient for SOA formation and that are emitted both constitutively as well as induced, highlighted the numerous difficulties associated with measurements that prevents identification of processes and natural variability required for development of suitable algorithms (Duhl et al., 2008). For methanol, with a terrestrial source at least as large as monoterpenes, a global concept was developed by Galbally and Kirstine (2002) that seeks to account for the observed variation of emissions in response to cellular expansion during vegetation growth.

\subsubsection{Ozone effects on vegetation}

A limited number of continental to global scale modelling studies suggest $\mathrm{O}_{3}$ induced reductions in productivity and land carbon storage over North America, Europe, China, and India (Felzer et al., 2004; Ren et al., 2007; Sitch et al., 2007), regions with high levels of human appropriation of primary productivity (Imhoff et al., 2004). A meta-analysis of $\mathrm{O}_{3}$ experiments has shown reductions in the light-saturated photosynthesis and stomatal conductance in trees of $11 \%$ and $13 \%$, respectively, as a likely response of plants to elevated $\mathrm{O}_{3}$ exposure compared to pre-industrial levels (Wittig et al., 2007). However, McLaughlin et al. (2007) found decreased growth but increased water use in mature forest trees under high ambient $\mathrm{O}_{3}$ concentrations, with $\mathrm{O}_{3}$ exposure leading to reduced stomatal control of water loss and delayed stomatal closure at night. Free Air $\mathrm{CO}_{2}$ Enrichment (FACE) and related experiments using ozone-enriched air indicate a nonlinear interaction between plant responses to $\mathrm{CO}_{2}$ and $\mathrm{O}_{3}$. Models of plant- $\mathrm{O}_{3}$ interactions must be able to replicate results obtained in the enrichment experiments, e.g., for aspen trees (Karnosky, 2003; Karnosky et al., 2005) or at a Swiss grassland site (Volk et al., 2006) where plots are exposed for multiple years to combinations of ambient and elevated concentrations of $\mathrm{CO}_{2}$ and $\mathrm{O}_{3}$.

In recent years there has been a shift towards the use of flux-based assessments (Emberson et al., 2000; Ashmore et al., 2004; Ashmore, 2005). A mechanistic model of plant$\mathrm{O}_{3}-\mathrm{CO}_{2}$ interactions was implemented into the Hadley Centre land-surface model (Sitch et al., 2007). The model assumes a suppression of net leaf photosynthesis by $\mathrm{O}_{3}$ that varies proportionally to the $\mathrm{O}_{3}$ flux through stomata above a specified critical $\mathrm{O}_{3}$ deposition flux. A novel aspect in adopting a flux-gradient approach to modelling leaf gas exchange of both $\mathrm{O}_{3}$ and $\mathrm{CO}_{2}$ is that it enables an investigation of not only the individual effects of $\mathrm{O}_{3}$ and $\mathrm{CO}_{2}$ acting in isolation on plant physiology, but also of their interaction. These are typically ignored in modelling approaches that are based on cumulative $\mathrm{O}_{3}$ exposure, e.g. $\mathrm{AOT}_{40}$ (accumulated dose over a threshold of $40 \mathrm{ppb}$ ) metric, rather than on uptake by leaves.

The model of Sitch et al. (2007) was applied using $\mathrm{O}_{3}$ concentrations previously generated using the STOCHEM chemistry-transport model, which in turn was driven using emissions from the SRES A2 scenario (Sanderson et al., 2003a; Sitch et al., 2007). Results suggest a large negative impact of near-surface $\mathrm{O}_{3}$ on plant productivity, and a significant suppression of the global land carbon sink of up to 260 $\mathrm{PgC}$ by 2100 (Sitch et al., 2007). The additional $\mathrm{CO}_{2}$ left in the atmosphere caused by $\mathrm{O}_{3}$-induced damage to plants constitutes an indirect radiative forcing that could exceed warming due to the direct radiative effect of tropospheric $\mathrm{O}_{3}$ increases (Sitch et al., 2007). However, elevated $\mathrm{CO}_{2}$ concentrations provide a degree of protection against $\mathrm{O}_{3}$ damage via $\mathrm{CO}_{2}$ induced reductions in stomatal conductance which was found to off-set $\mathrm{O}_{3}$ suppression of GPP by over one-third (Sitch et al., 2007). Dry deposition fluxes may also change, owing to stomatal closure at elevated $\mathrm{CO}_{2}$ levels and changes in soil moisture and biogeography. Sanderson et al. (2007) found that surface ozone levels over parts of Europe were 
6-8 ppb larger under doubled $\mathrm{CO}_{2}$ conditions, owing to the reduced dry deposition sink.

Global models currently assume that $\mathrm{O}_{3}$ effects are representative for all plants and their respective age-classes, and assume a constant $\mathrm{O}_{3}$ flux response of all plants throughout the growing period. There are significant uncertainties in the response of different plant species to $\mathrm{O}_{3}$, especially for tropical ecosystems. Generally, crops are most sensitive, angiosperms intermediate and conifers the least sensitive to $\mathrm{O}_{3}$ exposure (Reich, 1987). Recent evidence points towards a possible protective role of isoprene and monoterpenes against $\mathrm{O}_{3}$ damage (Loreto and Velikova, 2001; Fares et al., 2008). Within crop types, wheat is considered sensitive and potato less sensitive to $\mathrm{O}_{3}$ exposure (Pleijel et al., 2004). But there are disadvantages of sowing $\mathrm{O}_{3}$ tolerant crop varieties since they tend to have lower yields than non-resistant varieties. Also, only a few studies relate cumulative uptake of $\mathrm{O}_{3}$ over a growing season to yield reduction for different vegetation types (Karlsson et al., 2004; Pleijel et al., 2004).

\section{Future challenges: model integration and evaluation}

For an improved representation of non- $\mathrm{CO}_{2}$ trace gas exchange in global models several scaling problems need to be resolved, associated with increasing resolution and detail of process representation: (i) representation of soils with different physico-chemical properties (i.e. texture, $\mathrm{pH}$ ) within a DGVM grid cells, (ii) representation of soil moisture heterogeneity and redox status, both in terms of vertical and horizontal sub-grid scale distribution of water, including lateral flows for (seasonal) wetland extent, (iii) representation of vegetation, both in terms of vertical and horizontal subgrid heterogeneity to appropriately capture vegetation dynamics and trace gas emission interactively, (iv) accounting for within canopy and boundary layer processes affecting both emission and deposition processes, (v) specification of land management practices in terms of fertiliser types and application methods and timing for semi-natural and cropland ecosystems. Moreover, not all DGVMs operate at the short time-steps required to link trace gas emissions and atmospheric chemistry. Progress in these areas is non-trivial due to lack in mechanistic understanding, computational expense as well as structural differences between off-line DGVMs and land surface schemes applied in coupled global models. Hence, there are possible conflicts between model complexity and efficiency. This requires a pragmatic approach to be adopted both in terms of processes as well as evaluation.

By coupling a trace gas enabled DGVM to a CTM, a wide variety of trace gas measurements could be utilised in model evaluation, thereby expanding on the previously developed methodology for carbon, and to evaluate the interdependencies of the various trace gases and GHGs. DGVM outputs can also inform the CTMs about deposition parameters such as LAI, stomatal conductance and roughness length. This strategy links emissions/sinks of reactive trace gases and concentration observations. Numerous trace-gas measurements are available including historical data from ice-cores $\left(\mathrm{H}_{2}\right.$, $\mathrm{CO}_{2}, \mathrm{CH}_{4}$ ), continuous measurements using high frequency gas chromatographs at a global network of flask $\left(\mathrm{CH}_{4}, \mathrm{~N}_{2} \mathrm{O}\right.$, $\mathrm{CO}_{2}$, CO; Prinn et al., 2000) and aircraft measurements $\left(\mathrm{CO}_{2}, \mathrm{CH}_{4}, \mathrm{CO}, \mathrm{H}_{2}\right)$ (http://cdiac.ornl.gov/tracegases.html). In addition isotopes, ${ }^{13} \mathrm{C}$ (in $\mathrm{CO}, \mathrm{CO}_{2}, \mathrm{CH}_{4}$ ), ${ }^{14} \mathrm{C}$ (in $\mathrm{CO}_{2}$ ), ${ }^{18} \mathrm{O}, \delta^{2} \mathrm{H}$ are available at a subset of stations. However, the appropriate model evaluation protocol is not fully developed and has been attempted only in a few regional studies, and for a limited number of substances (e.g., Palmer et al., 2003; Barkley et al., 2008). A major uncertainty arises since model-data mismatch in trace gas concentrations at monitoring sites may be related to emission estimates, but also to shortcomings in the modelled chemical degradation and transport mechanisms.

\section{Outlook}

Here we present the collective advances within the DGVM community on simulating non- $\mathrm{CO}_{2}$ trace-gas exchange at the land surface. At present no single DGVM represents yet all the major non- $\mathrm{CO}_{2}$ trace gas exchange processes identified in this review. Model intercomparison will be desirable and necessary in the near future once individual DGVMs include representations of all major processes relevant to non- $\mathrm{CO}_{2}$ trace gas exchange.

While the atmospheric importance of non- $\mathrm{CO}_{2}$ trace gases is generally understood, their overall climate and atmospheric chemistry effects are uncertain. Apparent, however, from a number of recent studies is that the incorporation of biological process-understanding as part of dynamic emission simulations is important and may yield surprises in the chemistry-climate system. For example, a direct $\mathrm{CO}_{2}-$ BVOC effect (Arneth et al., 2007a) may lead to larger than thought BVOC emissions at LGM atmospheric $\mathrm{CO}_{2}$ concentrations. This suggests either larger changes in $\mathrm{CH}_{4}$ wetland emissions than estimated by biogeochemical models, or invokes additional processes (Lelieveld et al., 2008). However, Wilkinson et al argue for a lower sensitivity of isoprene production at low atmospheric $\mathrm{CO}_{2}$ levels (Wilkinson et al., 2009). $\mathrm{CO}_{2}$-BVOC inhibition also questions the proposed negative temperature feedback of higher aerosol formation from larger BVOC (particularly monoterpenes) emissions in the future (Kulmala et al., 2004), but BVOC- $\mathrm{CO}_{2}$ interactions in plant species that emit terpenoids from storage are not yet resolved. Together with $\mathrm{NO}_{\mathrm{x}}, \mathrm{BVOC}$ are important precursors of $\mathrm{O}_{3}$, and reductions in $\mathrm{BVOC}$ in a $\mathrm{CO}_{2}$ enriched world may reduce regional $\mathrm{O}_{3}$ concentrations (Young et al., 2009). Future regional changes in near-surface $\mathrm{O}_{3}$ concentrations are important given the phytotoxicity of $\mathrm{O}_{3}$ and the potential for considerable reductions in the land carbon sink, constituting indirect radiative forcing of climate (Sitch et al., 
2007). Comparatively low $\mathrm{N}_{2} \mathrm{O}$ emissions are associated with oil palm, and ligno-cellulosic plants (e.g., poplar, willow), compared to other agro-biofuel production for which emission estimates are potentially 2-3 times higher than previously assumed (Crutzen et al., 2008). However almost all fast growing agri-forest tree species are high isoprene emitters (Rosenstiel et al., 2003).

These examples reinforce the important need for an integrated approach to modelling land use, biota, chemistry and climate and the need for a full evaluation of the effectiveness of land management as a tool to mitigate climate change in an integrated DGVM, climate-chemistry model framework. Future DGVMs will be able to simulate spatial and temporal variations in non- $\mathrm{CO}_{2}$ trace gas exchange at the land surface, thereby going some way to address one of the major sources of uncertainty in atmospheric chemistry, air quality and climate science.

Acknowledgements. This work was supported by a European Commissions 6th FP Marie Curie Excellence Team grant. Research contributing to this review was funded by the Swedish Research Council Formas, and by the Linnée Excellence Centre for Studies of Carbon Cycle and Climate Interactions. The authors acknowledge discussions at the Marie-Curie iLEAPS science meeting in Helsingborg to stimulate the development of this manuscript. Figure 1 is adopted from P. Artaxo, unpublished. N. Gedney, M. Sanderson and S. Sitch were supported by the Joint DECC and Defra Integrated Climate Programme - DECC/Defra (GA01101).

Edited by: G. Wohlfahrt

\section{References}

Adams, J. M., Constable, J. V. H., Guenther, A. B., and Zimmerman, P.: An estimate of natural volatile organic compound emissions from vegetation since the last glacial maximum, Chemosphere, 3, 73-91, 2001.

Anderson, J. M.: Breakdown and decomposition of sweet chestnut (Castanea sativa mill.) and beech (Fagus sylvatica 1.) leaf litter in 2 deciduous woodland soils. 1. Breakdown, leaching and decomposition, Oecologia, 12, 251-274, 1973.

Andreae, M. O. and Crutzen, P. J.: Atmospheric aerosols: Biogeochemical sources and role in atmospheric chemistry, Science, 276, 1052-1058, doi:1010.1126/science.1276.5315.1052, 1997.

Andreae, M. O. and Merlet, P.: Emission of trace gases and aerosols from biomass burning, Global Biogeochem. Cy., 15, 955-966, 2001.

Andreae, M. O.: Aerosols before pollution, Science, 315, 50-51, doi:10.1126/science.1136529, 2007.

Arneth, A., Miller, P. A., Scholze, M., Hickler, T., Schurgers, G., Smith, B., and Prentice, I. C.: $\mathrm{CO}_{2}$ inhibition of global terrestrial isoprene emissions: Potential implications for atmospheric chemistry, Geophys. Res. Lett., 34, L18813, doi:18810.11029/12007GL030615, 2007a.

Arneth, A., Niinemets, Ü., Pressley, S., Bäck, J., Hari, P., Karl, T., Noe, S., Prentice, I. C., Serça, D., Hickler, T., Wolf, A., and Smith, B.: Process-based estimates of terrestrial ecosystem isoprene emissions: incorporating the effects of a direct $\mathrm{CO} 2-$ isoprene interaction, Atmos. Chem. Phys., 7, 31-53, 2007b, http://www.atmos-chem-phys.net/7/31/2007/.

Arneth, A., Monson, R. K., Schurgers, G., Niinemets, ., and Palmer, P. I.: Why are estimates of global terrestrial isoprene emissions so similar (and why is this not so for monoterpenes)?, Atmos. Chem. Phys., 8, 4605-4620, 2008a, http://www.atmos-chemphys.net/8/4605/2008/.

Arneth, A., Schurgers, G., Hickler, T., and Miller, P. A.: Effects of species composition, land surface cover, $\mathrm{CO}_{2}$ concentration and climate on isoprene emissions from european forests, Plant Biol., 10, 150-162, doi:110.1055/s-2007-965247, 2008 b.

Ashmore, M. L., Emberson, L., Karsson, P. E., and Pleijel, H.: A new generation of ozone critical levels for the protection of vegetation in europe, Atmos. Environ., 38, 2213-2214, 2004.

Ashmore, M. R.: Assessing the future global impacts of ozone on vegetation, Plant Cell Environ., 28, 949-964, 2005.

Barket Jr., D. J., Grossenbacher, J. W., Hurst, J. M., Shepson, P. B., Olszyna, K., Thornberry, T., Carroll, M. A., Roberts, J., Stround, C., Bottenheim, J., and Biesenthal, T.: A study of the $\mathrm{NO}_{\mathrm{x}}$ dependence of isoprene oxidation, J. Geophys. Res., 109, D11310, doi:11310.11029/12003JD003965, 2004.

Barkley, M. P., Palmer, P. I., Kuhn, U., Kesselmeier, J., Chance, K., Kurosu, T. P., Martin, R. V., Helmig, D., and Guenther, A.: Net ecosystem fluxes of isoprene over tropical South America inferred from GOME observations of HCHO columns, J. Geophys. Res., 113, D20304, doi:10.1029/2008jd009863, 2008.

Batjes, N. H.: A homogenised soil profile data set for global and regional environmental research (wise, version 1.1), Int. Soil Ref. and Inf. Center, Wageningen, 2002.

Beer, C., Lucht, W., Gerten, D., Thonicke, K., and Schmullius, C.: Effects of soil freezing and thawing on vegetation carbon density in Siberia: A modeling analysis with the Lund-PotsdamJena dynamic global vegetation model (LPJ-DGVM), Global Biogeochem. Cy., 21, Gb1012, doi:1010.1029/2006GB002760, 2007.

Bian, H., Chin, M., Kawa, S. R., Duncan, B., Arellano, A., and Kasibhatla, P.: Sensitivity of global co simulations to uncertainties in biomass burning sources, J. Geophys. Res.-Atmos., 112, D23308, doi:23310.21029/22006JD008376, 2007.

Bond-Lamberty, B., Peckham, S. D., Ahl, D. E., and Gower, S. T.: Fire as the dominant driver of central Canadian boreal forest carbon balance, Nature, 450, 89-92, doi:10.1038/nature06272, 2007.

Bondeau, A., Smith, P. C., Zaehle, S., Schaphoff, S., Lucht, W., Cramer, W., Gerten, D., Lotze-Campen, H., Muller, C., Reichstein, M., and Smith, B.: Modelling the role of agriculture for the 20th century global terrestrial carbon balance, Glob. Change Biol., 13, 679-706, doi:10.1111/j.13652486.2006.01305.x, 2007.

Bonn, B. and Moortgat, G. K.: Sesquiterpene ozonolysis: Origin of atmospheric new particle formation from biogenic hydrocarbons, Geophys. Res. Lett., 30, 1585, doi:1510.1029/2003GL017000, 2003.

Bousquet, P., Ciais, P., and Miller, J. B.: Contribution of anthropogenic and natural sources to atmospheric methane variability, Nature, 443, 439-443, 2006.

Bouwman, A. F., Boumans, L. J. M., and Batjes, N. H.: Estimation of global $\mathrm{NH}_{3}$ volatilization loss from synthetic fertilizers and 
animal manure applied to arable lands and grasslands, Global Biogeochem. Cy., 16(2), 1024, doi:10.1029/2000GB001389, 2002.

Boyer, E. W., Alexander, R. B., Parton, W. J., Li, C. S., ButterbachBahl, K., Donner, S. D., Skaggs, R. W., and Del Gross, S. J.: Modeling denitrification in terrestrial and aquatic ecosystems at regional scales, Ecol. Appl., 16, 2123-2142, 2006.

Brisson, N., Ruget, F., Gate, P., Lorgeau, J., Nicoullaud, B., Tayot, X., Plenet, D., Jeuffroy, M. H., Bouthier, A., Ripoche, D., Mary, B., and Justes, E.: Stics: A generic model for simulating crops and their water and nitrogen balances. Ii. Model validation for wheat and maize, Agronomie, 22, 69-92, 2002.

Brovkin, V., Sitch, S., von Bloh, W., Claussen, M., Bauer, E., and Cramer, W.: Role of land cover changes for atmospheric $\mathrm{CO}_{2}$ increase and climate change during the last 150 years, Glob. Change Biol., 10, 1253-1266, 2004.

Bruisma, J.: World agriculture: Towards 2015/2030: An fao study, FAO, London, Earthscan Publications, 2003.

Brummer, C., Bruggemann, N., Butterbach-Bahl, K., Falk, U., Szarzynski, J., Vielhauer, K., Wassmann, R., and Papen, H.: Soil-atmosphere exchange of $\mathrm{N}_{2} \mathrm{O}$ and $\mathrm{NO}$ in near-natural savanna and agricultural land in Burkina Faso (W. Africa), Ecosystems, 11, 582-600, doi:10.1007/s10021-008-9144-1, 2008.

Buchwitz, M., de Beek, R., Burrows, J. P., Bovensmann, H., Warneke, T., Notholt, J., Meirink, J. F., Goede, A. P. H., Bergamaschi, P., Körner, S., Heimann, M., and Schulz, A.: Atmospheric methane and carbon dioxide from SCIAMACHY satellite data: initial comparison with chemistry and transport models, Atmos. Chem. Phys., 5, 941-962, 2005, http://www.atmoschem-phys.net/5/941/2005/.

Butterbach-Bahl, K., Kesik, M., Miehle, P., Papen, H., and Li, C.: Quantifying the regional source strength of n-trace gases across agricultural and forest ecosystems with process based models, Plant Soil, 260, 311-329, 2004.

Butterbach-Bahl, K., Kahl, M., Mykhayliv, I., Werner, C., Kiese, R., and $\mathrm{Li}, \mathrm{C}$. : European wide inventory of soil no emissions using the biogeochemical models DNDC/forest DNDC, Atmos. Environ., 43(7), 1392-1402, doi:10.1016/j.atmosenv.2008.02.008, 2008.

Cao, M., Marshall, S., and Gregson, K.: Global carbon exchange and methane emission from natural wetlands: Application of a process-based model, J. Geophys. Res., 101, 143999-114414, 1996.

Cao, M., Gregson, K., and Marshall, S.: Global methane emission from wetlands and its sensitivity to climate change, Atmos. Environ., 32, 3293-3299, 1998.

Challinor, A. J., Wheeler, T. R., Craufurd, P. Q., Slingo, J. M., and Grimes, D. I. F.: Design and optimisation of a large-area processbased model for annual crops, Agr. Forest Meteorol., 124, 99120,2004

Challinor, A., Wheeler, T., Garforth, C., Craufurd, P., and Kassam, A.: Assessing the vulnerability of food crop systems in Africa to climate change, Climatic Change, 83, 381-399, 2007.

Chameides, W. L., Lindsay, R. W., Richardson, J., and Kiang, C. S.: The role of biogenic hydrocarbons in urban photochemical smog, Science, 241, 1-10, 1988.

Chapuis-Lardy, L., Wrage, N., Metay, A. U. R., Chotte, J.-L., and Bernoux, M.: Soils, a sink for $\mathrm{N}_{2} \mathrm{O}$ ? A review, Glob. Change Biol., 13, 1-17, 2007.
Chen, Y. H. and Prinn, R. G.: Estimation of atmospheric methane emissions between 1996 and 2001 using a three-dimensional global chemical transport model, J. Geophys. Res.-Atmos., 111, D10307, doi:10310.11029/12005JD006058, 2006.

Christensen, T. R., Prentice, I. C., Kaplan, J., Haxeltine, A., and Sitch, S.: Methane flux from northern wetlands and tundra: An ecosystem source modelling approach, Tellus, 48B, 651-660, 1996.

Christensen, T. R., Ekberg, A., Strom, L., Mastepanov, M., Panikov, N., Mats, O., Svensson, B. H., Nykanen, H., Martikainen, P. J., and Oskarsson, H.: Factors controlling large scale variations in methane emissions from wetlands, Geophys. Res. Lett., 30, 1414, doi:1410.1029/2002L016848, 2003.

Christensen, T. R., Johansson, T., Åkerman, H. J., and Mastepanov, M.: Thawing sub-arctic permafrost: Effects on vegetation and methane emissions, Geophys. Res. Lett., 31, L04501, doi:04510.01029/02003GJ018680, 2004.

Ciais, P., Tans, P. P., Trolier, M., White, J. W. C., and Francey, R. J.: A large northern hemisphere terrestrial $\mathrm{CO}_{2}$ sink indicated by the ${ }^{13} \mathrm{C} /{ }^{12} \mathrm{C}$ ratio of atmospheric $\mathrm{CO}_{2}$, Science, 269, 1098-1102, doi:10.1126/science.269.5227.1098, 1995.

Collatz, G. J., Ball, J. T., Grivet, C., and Berry, J. A.: Physiological and environmental regulation of stomatal conductance, photosynthesis and transpiration: A model that includes a laminar boundary layer, Agr. Forest Meteorol., 54, 107-136, 1991.

Conrad, R.: Soil microorganisms as controllers of atmospheric trace gases ( $\mathrm{H}-2, \mathrm{CO}, \mathrm{CH}_{4}, \mathrm{OCS}, \mathrm{N}_{2} \mathrm{O}$, and $\mathrm{NO}$ ), Microbiol. Rev., 60, 609-640, 1996.

Cox, P. M., Betts, R. A., Jones, C. D., Spall, S. A., and Totterdell, I. J.: Acceleration of global warming due to carbon-cycle feedbacks in a coupled climate model, Nature, 408, 184-186, 2000.

Coyle, M., Nemitz, E., Storeton-West, R. L., Fowler, D., and Cape, J. N.: Measurements of ozone deposition to a potato canopy, Agr. Forest Meteorol., 149, 655-666, 2009.

Cramer, W., Bondeau, A., Woodward, F. I., Prentice, I. C., Betts, R. A., Brovkin, V., Cox, P. M., Fisher, V., Foley, J. A., Friend, A. D., Kucharik, C., Lomas, M., Ramankutty, N., Sitch, S., Smith, B., White, A., and Young-Molling, C.: Global response of terrestrial ecosystem structure and function to $\mathrm{CO}_{2}$ and climate change: Results from six dynamic global vegetation models, Glob. Change Biol., 7, 357-373, 2001.

Crutzen, P. J.: Role of $\mathrm{NO}$ and $\mathrm{NO}_{2}$ in the chemistry of the troposphere and stratosphere, Annu. Rev. Earth Planet. Sci., 7, 443472, 1979.

Crutzen, P. J., Mosier, A. R., Smith, K. A., and Winiwarter, W.: $\mathrm{N}_{2} \mathrm{O}$ release from agro-biofuel production negates global warming reduction by replacing fossil fuels, Atmos. Chem. Phys., 8, 389-395, 2008, http://www.atmos-chem-phys.net/8/389/2008/.

Curry, C. L.: Modeling the soil consumption of atmospheric methane at the global scale, Global Biogeochem. Cy., 21, GB4012, doi:10.1029/2006GB002818, 2007.

Davin, E. L., de Noblet-Ducoudré, N., and Friedlingstein, P.: Impact of land cover change on surface climate: Relevance of the radiative forcing concept, Geophys. Res. Lett., 34, L13702, doi:13710.11029/12007GL029678, 2007.

de Noblet-Ducoudré, N., Gervois, S., Ciais, P., Viovy, N., Brisson, N., Seguin, B., and Perrier, A.: Coupling the soil-vegetationatmosphere-transfer scheme ORCHIDEE to the agronomy model STICS to study the influence of croplands on the European car- 
bon and water budgets, Agronomie, 24, 397-407, 2004.

Del Gross0, S. J., Parton, W. J., Mosier, A. R., Walsh, M. K., Ojima, D. S., and Thornton, P. E.: Daycent national-scale simulations of nitrous oxide emissions from cropped soils in the United States, J. Environ. Qual., 35, 1451-1460, 2006.

Denman, K. L., Brasseur, G., Chidtaisong, A., Ciais, P., Cox, P. M., Dickinson, R. E., Hauglustaine, D., Heinze, C., Holland, E., Jacob, D., Lohmann, U., Ramachandran, S., Leita da Silva Dias, P., Wofsy, S. C., Zhang, X., et al.: Couplings between changes in the climate system and biogeochemistry, in: Climate change 2007: The physical science basis. Contribution of working group I to the Fourth Assessment Report of the Intergovernmental Panel on Climate Change, edited by: Solomon, S., Qin, D., Manning, M., et. al., Cambridge University Press, Cambridge, 2007.

Denning, A. S. and Fung, I. Y.: Latitudinal gradient of atmospheric $\mathrm{CO}_{2}$ due to seasonal exchange with land biota, Nature, 376, 240243, 1995.

Dentener, F., Stevenson, D., Ellingsen, K., van Noije, T., Schultz, M., Amann, M., Atherton, C., Bell, N., Bergmann, D., Bey, I., Bouwman, L., Butler, T., Cofala, J., Collins, B., Drevet, J., Doherty, R., Eickhout, B., Eskes, H., Fiore, A., Gauss, M., Hauglustaine, D., Horowitz, L., Isaksen, I. S. A., Josse, B., Lawrence, M., Krol, M., Lamarque, J. F., Montanaro, V., Muller, J. F., Peuch, V. H., Pitari, G., Pyle, J., Rast, S., Rodriguez, J., Sanderson, M., Savage, N. H., Shindell, D., Strahan, S., Szopa, S., Sudo, K., Van Dingenen, R., Wild, O., and Zeng, G.: The global Atmos. Environ. for the next generation, Environ. Sci. Technol., 40, 35863594, 2006a.

Dentener, F., Drevet, J., Lamarque, J. F., Bey, I., Eickhout, B., Fiore, A. M., Hauglustaine, D., Horowitz, L. W., Krol, M., Kulshrestha, U. C., Lawrence, M., Galy-Lacaux, C., Rast, S., Shindell, D., Stevenson, D., Van Noije, T., Atherton, C., Bell, N., Bergman, D., Butler, T., Cofala, J., Collins, B., Doherty, R., Ellingsen, K., Galloway, J., Gauss, M., Montanaro, V., Muller, J. F., Pitari, G., Rodriguez, J., Sanderson, M., Solmon, F., Strahan, S., Schultz, M., Sudo, K., Szopa, S., and Wild, O.: Nitrogen and sulfur deposition on regional and global scales: A multimodel evaluation, Global Biogeochem. Cy., 20, GB4003, doi:10.1029/2005GB002672, 2006b.

Derwent, R. G.: Air chemistry and terrestrial gas emissions: A global perspective, Philosophical Transactions of the Royal Society of London Series A, 351, 205-217, 1995.

Dickinson, M. B. and Johnson, E. A.: Fire effects on trees, in: Forest fires. Behaviour and ecological effects, edited by: Johnson, E. A. and Miyanishi, K., Academic Press, San Diego, 477-525, 2001.

Dickinson, R. E., Berry, J. A., Bonan, G. B., Collatz, G. J., Field, C. B., Fung, I. Y., Goulden, M., Hoffmann, W. A., Jackson, R. B., Myneni, R., Sellers, P. J., and Shaikh, M.: Nitrogen controls on climate model evapotranspiration, J. Climate, 15, 278-295, 2002.

Donner, L. and Ramanathan, V.: Methane and nitrous oxide: Their effects on the terrestrial climate, J. Atmos. Sci., 37, 119-124, 1980.

Donner, S. D. and Kucharik, C. J.: Evaluating the impacts of land management and climate variability on crop production and nitrate export across the Upper Mississippi Basin, Global Biogeochem. Cy., 17, 1050, doi:1010.1029/2001GB001808, 2003.

Donner, S. D., Kucharik, C. J., and Foley, J. A.: Impact of changing land use practices on nitrate export by the Mississippi river, Global Biogeochem. Cy., 18, GB1028, doi:1010.1029/ 2003GB002093, 2004.

Dueck, T. A., de Visser, R., Poorter, H., Persijn, S., Gorissen, A., de Visser, W., Schapendonk, A., Verhagen, J., Snel, J., Harren, F. J. M., Ngai, A. K. Y., Verstappen, F., Bouwmeester, H., Voesenek, L., and van der Werf, A.: No evidence for substantial aerobic methane emission by terrestrial plants: A C-13-labelling approach, New Phytol., 175, 29-35, 2007.

Duhl, T. R., Helmig, D., and Guenther, A.: Sesquiterpene emissions from vegetation: a review, Biogeosciences, 5, 761-777, 2008, http://www.biogeosciences.net/5/761/2008/.

Duncan, B. N., Logan, J. A., Bey, I., Megretskaia, I. A., Yantosca, R. M., Novelli, P. C., Jones, N. B., and Rinsland, C. P.: Global budget of co, 1988-1997: Source estimates and validation with a global model, J. Geophys. Res.-Atmos., 112, D22301, doi:22310.21029/22007JD008459, 2007.

Dusek, U., Frank, G. P., Hildebrandt, L., Curtius, J., Schneider, J., Walter, S., Chand, D., Drewnick, F., Hings, S., Jung, D., Borrmann, S., and Andreae, M. O.: Size matters more than chemistry for cloud-nucleating ability of aerosol particles, Science, 312, 1375-1378, doi:10.1126/science.1125261, 2006.

Dutaur, L. and Verchot, L. V.: A global inventory of the soil CH4 sink, Global Biogeochem. Cy., 21, GB4013, doi:10.1029/2006gb002734, 2007.

Emberson, L. D., Ashmore, M. R., Cambridge, H. M., Simpson, D., and Tuovinen, J. P.: Modelling stomatal ozone flux across Europe, Environ. Pollut., 109, 403-413, 2000.

Euskirchen, E. S., McGuire, A. D., Kicklighter, D. W., Zhuang, Q., Clein, J. S., Dargaville, R. J., Dye, D. G., Kimball, J. S., McDonald, K. C., Melillo, J. M., Romanovsky, V. E., and Smith, N. V.: Importance of recent shifts in soil thermal dynamics on growing season length, productivity, and carbon sequestration in terrestrial high-latitude ecosystems, Glob. Change Biol., 12, 731-750, 2006.

Fares, S., Loreto, F., Kleist, E., and Wildt, J.: Stomatal uptake and stomatal deposition of ozone in isoprene and monoterpene emitting plants, Plant Biol., 10, 44-54, doi:10.1055/s-2007-965257, 2008.

Farquhar, G. D., von Caemmerer, S., and Berry, J. A.: A biochemical model of photosynthetic $\mathrm{CO}_{2}$ assimilation in leaves of $\mathrm{C}_{3}$ species, Planta, 149, 78-90, 1980.

Feddema, J. J., Oleson, K. W., Bonan, G. B., Mearns, L. O., Buja, L. E., Meehl, G. A., and Washington, W. M.: The importance of land-cover change in simulating future climates, Science, 310, 1674-1678, 2005.

Felzer, B., Kicklighter, D., Melillo, J., Wang, C., Zhuang, Q., and Prinn, R.: Effects of ozone on net primary production and carbon sequestration in the conterminous united states using a biogeochemistry model, Tellus B, 56, 230-248, 2004.

Feng, Y. and Penner J. E.: Global modelling of nitrate and ammonium: Interaction of aerosols and tropospheric chemistry, J. Geophys. Res., 112, D01304, doi:10.1029/2005JD006404, 2007.

Ferretti, D. F., Miller, J. B., White, J. W. C., Lassey, K. R., Lowe, D. C., and Etheridge, D. M.: Stable isotopes provide revised global limits of aerobic methane emissions from plants, Atmos. Chem. Phys., 7, 237-241, 2007, http://www.atmos-chemphys.net/7/237/2007/.

Finzi, A. C., Norby, R. J., Calfapietra, C., Gallet-Budynek, A., 
Gielen, B., Holmes, W. E., Hoosbeek, M. R., Iversen, C. M., Jackson, R. B., Kubiske, M. E., Ledford, J., Liberloo, M., Oren, R., Polle, A., Pritchard, S., Zak, D. R., Schlesinger, W. H., and Ceulemans, R.: Increases in nitrogen uptake rather than nitrogenuse efficiency support higher rates of temperate forest productivity under elevated $\mathrm{CO}_{2}$, P. Natl. Acad. Sci., 104, 14014-14019, doi:10.1073/pnas.0706518104, 2007.

Fiore, A. M., Dentener, F. J., Wild, O., Cuvelier, C., Schultz, M. G., Hess, P., Textor, C., Schulz, M., Doherty, R. M., Horowitz, L. W., MacKenzie, I. A., Sanderson, M. G., Shindell, D. T., Stevenson, D. S., Szopa, S., Van Dingenen, R., Zeng, G., Atherton, C., Bergmann, D., Bey, I., Carmichael, G., Collins, W. J., Duncan, B. N., Faluvegi, G., Folberth, G., Gauss, M., Gong, S., Hauglustaine, D., Holloway, T., Isaksen, I. S. A., Jacob, D. J., Jonson, J. E., Kaminski, J. W., Keating, T. J., Lupu, A., Marmer, E., Montanaro, V., Park, R. J., Pitari, G., Pringle, K. J., Pyle, J. A., Schroeder, S., Vivanco, M. G., Wind, P., Wojcik, G., $\mathrm{Wu}$, S., and Zuber, A.: Multimodel estimates of intercontinental source-receptor relationships for ozone pollution, J. Geophys. Res.-Atmos., 114, D04301, doi:10.1029/2008jd010816, 2009.

Fischer, G., Vetlthuizen, H., Shah, M. M., and Nachtergale, F.: Global agro-ecological assessment for agriculture in the 21st century: Methodology and results, IIASA, Laxenburg, Austria, 155 pp., 2002.

Fischer, H., Behrens, M., Bock, M., Richter, U., Schmitt, J., Loulergue, L., Chappellaz, J., Spahni, R., Blunier, T., Leuenberger, M., and Stocker, T. F.: Changing boreal methane sources and constant biomass burning during the last termination, Nature, 452, 864-867, 2008.

Fiscus, E. L., Booker, F. L., and Burkey, K. O.: Crop responses to ozone: Uptake, modes of action, carbon assimilation and partitioning, Plant Cell Environ., 28, 997-1011, doi:10.1111/j.13653040.2005.01349.x, 2005.

Folberth, G. A., Hauglustaine, D. A., Lathiére, J., and Brocheton, F.: Interactive chemistry in the Laboratoire de Mtorologie Dynamique general circulation model: model description and impact analysis of biogenic hydrocarbons on tropospheric chemistry, Atmos. Chem. Phys., 6, 2273-2319, 2006, http://www.atmos-chem-phys.net/6/2273/2006/.

Foley, J. A., Prentice, I. C., Ramankutty, N., Levis, S., Pollard, D., Sitch, S., and Haxeltine, A.: An integrated biosphere model of land surface processes, terrestrial carbon balance, and vegetation dynamics, Global Biogeochem. Cy., 10, 603-628, 1996.

Forster, P., Ramaswamy, V., Artaxo, P., Berntsen, T., Betts, R., Fahey, D. W., Haywood, J., Lean, J., Lowe, D. C., Myhre, G., Nganga, J., Prinn, R., Raga, G., Schultz, M., van Dorland, R., et al.: Changes in atmospheric constituents and radiative forcing, in: Climate change 2007: The physical science basis. Contribution of working group I to the Fourth Assessment Report of the Intergovernmental Panel on Climate Change, edited by: Solomon, S., Qin, D., Manning, M., Chen, Z., Marquis, M., Averyt, K. B., Tignor, M., and Miller, H. L., Cambridge University Press, Cambridge, United Kingdom and New York, NY, USA, 2007.

Fowler, D., Flechard, C., Cape, J. N., Storeton-West, R. L., and Coyle, M.: Measurements of ozone deposition to vegetation quantifying the flux, the stomatal and non-stomatal components, Water Air Soil Pollut., 130, 63-74, 2001.

Frankenberg, C., Meirink, J. F., van Weele, M., Platt, U., and Wag- ner, T.: Assessing methane emissions from global space-borne observations, Science, 308, 1010-1014, 2005.

Friborg, T., Soegaard, H., Christensen, T. R., Lloyd, C. R., and Panikov, N. S.: Siberian wetlands: Where a sink is a source, Geophys. Res. Lett., 30, 2129, doi:2110.1029/2003GL017797, 2003.

Friedlingstein, P., Bopp, L., Ciais, P., Dufresne, J.-L., Fairhead, L., LeTreut, H., Monfray, P., and Orr, J.: Positive feedback between future climate change and the carbon cycle, Geophys. Res. Lett., 28, 1543-1546, 2001.

Friedlingstein, P., Cox, P., Betts, R., Bopp, L., Von Bloh, W., Brovkin, V., Cadule, P., Doney, S., Eby, M., Fung, I., Bala, G., John, J., Jones, C., Joos, F., Kato, T., Kawamiya, M., Knorr, W., Lindsay, K., Matthews, H. D., Raddatz, T., Rayner, P., Reick, C., Roeckner, E., Schnitzler, K. G., Schnur, R., Strassmann, K., Weaver, A. J., Yoshikawa, C., and Zeng, N.: Climate-carbon cycle feedback analysis: Results from the (CMIP)-M-4 model intercomparison, J. Climate, 19, 3337-3353, 2006.

Friend, A. D., Stevens, A. K., Knox, R. G., and Cannell, M. G. R.: A process-based, terrestrial biosphere model of ecosystem dynamics (Hybrid v3.0), Ecol. Modell., 95, 249-287, 1997.

Friend, A. D., Arneth, A., Kiang, N. Y., Lomas, M., Ogee, J., Rodenbeckk, C., Running, S. W., Santaren, J. D., Sitch, S., Viovy, N., Woodward, F. I., and Zaehle, S.: Fluxnet and modelling the global carbon cycle, Glob. Change Biol., 13, 610-633, doi:610.1111/j.1365-2486.2006.01223.x, 2007.

Frolking, S. and Roulet, N. T.: Holocene radiative forcing impact of northern peatland carbon accumulation and methane emissions, Glob. Change Biol., 13, 1079-1088, doi:10.1111/j.13652486.2007.01339.x, 2007.

Fung, I., John, J., Lerner, J., Matthews, E., Prather, M., Steele, L. P., and Fraser, P. J.: 3-dimensionaml model synthesis of the global methane cycle, J. Geophys. Res., 96, 13033-13065, 1991.

Gabrielle, B., Laville, P., Duval, O., Nicoullaud, B., Germon, J. C., and Henault, C.: Process-based modeling of nitrous oxide emissions from wheat-cropped soils at the subregional scale, Global Biogeochem. Cy., 20, GB4018, doi:4010.1029/2006GB002686, 2006.

Galanter, M. and Levy, H.: Impact of biomass burning on tropospheric $\mathrm{CO}, \mathrm{NO}_{\mathrm{x}}$ and $\mathrm{O}_{3}$, J. Geophys. Res., 105, 6633-6653, 2000.

Galbally, I. E. and Kirstine, W.: The production of methanol by flowering plants and the global cycle of methanol, J. Atmos. Chem., 43, 195-229, doi:110.1023/A:1020684815474, 2002.

Galloway, J. N., Dentener, F. J., Capone, D. G., Boyer, E. W., Howarth, R. W., Seitzinger, S. P., Asner, G. P., Cleveland, C. C., Green, P. A., Holland, E. A., Karl, D. M., Michaels, A. F., Porter, J. H., Townsend, A. R., and Vorosmarty, C. J.: Nitrogen cycles: Past, present, and future, Biogeochemistry, 70, 153-226, 2004.

Galloway, J. N., Townsend, A. R., Erisman, J. W., Bekunda, M., Cai, Z., Freney, J. R., Martinelli, L. A., Seitzinger, S. P., and Sutton, M. A.: Transformation of the nitrogen cycle: Recent trends, questions, and potential solutions, Science, 320, 889892, doi:10.1126/science.1136674, 2008.

Ganzeveld, L. N., Lelieveld, J., Dentener, F. J., Krol, M. C., Bouwman, A. J., and Roelofs, G. J.: Global soil-biogenic NOx emissions and the role of canopy processes, J. Geophys. Res., 107, 4321, doi:10.1029/2001JD001289, 2002a. 
Ganzeveld, L. N., Lelieveld, J., Dentener, F. J., Krol, M. C., and Roelofs, G. J.: Atmosphere-biosphere trace gas exchanges simulated with a single-column model, J. Geophys. Res., 107, 4320, doi:10.1029/2001JD000684, 2002b.

Gauss, M., Myhre, G., Isaksen, I. S. A., Grewe, V., Pitari, G., Wild, O., Collins, W. J., Dentener, F. J., Ellingsen, K., Gohar, L. K., Hauglustaine, D. A., Iachetti, D., Lamarque, F., Mancini, E., Mickley, L. J., Prather, M. J., Pyle, J. A., Sanderson, M. G., Shine, K. P., Stevenson, D. S., Sudo, K., Szopa, S., and Zeng, G.: Radiative forcing since preindustrial times due to ozone change in the troposphere and the lower stratosphere, Atmos. Chem. Phys., 6, 575-599, 2006, http://www.atmos-chemphys.net/6/575/2006/.

Gedney, N., Cox, P. M., and Huntingford, C.: Climate feedback from wetland methane emissions, Geophys. Res. Lett., 31, L20503, doi:20510.21029/22004GL020919, 2004.

Gerten, D., Lucht, W., Schaphoff, S., Cramer, W., and Wagner, W.: Hydrologic resilience of the terrestrial biosphere, Geophys. Res. Lett., 32, L21408, doi:21410.21029/22005GL024247, 2005.

Gervois, S., De Noblet-Ducoudre, N., Viovy, N., Ciais, P., Brisson, N., Seguin, B., Perrier, A. Graedel, T. E., and Crutzen, P. J.: Including croplands in a global biosphere model: Methodology and evaluation on specific sites, Earth Interactions, 8, 1-25, 2004.

Gervois, S., Ciais, P., de Noblet-Ducoudre, N., Brisson, N., Vuichard, N., and Viovy, N.: Carbon and water balance of European croplands throughout the 20th century, Global Biogeochem. Cy., 22, GB2022, doi:10.1029/2007gb003018, 2008.

Graedel, T. E. and Crutzen, P. J.: Atmospheric change: An earth system perspective, W. H. Freeman and Company, New York, 1993.

Grant, R. F., Oechel, W. C., and Ping, C. L.: Modelling carbon balances of coastal arctic tundra under changing climate, Glob. Change Biol., 9, 16-36, 2003.

Groffman, P. M., Altabet, M. A., Böhlke, J. K., Butterbach-Bahl, K., M.B., D., Firestone, M. K., Giblin, A. E., Kana, T. M., Nielsen, L. P., and Voytek, M. A.: Methods for measuring denitrification: Diverse approaches to a difficult problem, Ecol. Appl., 16, 20912122, 2006.

Groffman P. M., Butterbach-Bahl, K., Fulweiler, R. W., Gold, A. J., Morse, J. L., Stander, E. K., Tague, C., Tonitto, C., and Vidon, P.: Challenges to incorporating spatially and temporally explicit phenomena (hotspots and hot moments), Biogeochemistry, 93, 49-77, 2009.

Gruber, N. and Galloway, J. N.: An earth-system perspective of the global nitrogen cycle, Nature, 451, 293-296, 2008.

Guenther, A., Monson, R. K., and Fall, R.: Isoprene and monoterpene emission rate variability: Observations with eucalyptus and emission rate algorithm development, J. Geophys. Res., 96, 10799-10808, 1991.

Guenther, A. B., Zimmerman, P. R., Harley, P. C., Monson, R. K., and Fall, R.: Isoprene and monoterpene emission rate variability - model evaluations and sensitivity analyses, J. Geophys. Res., 98, 12609-12617, 1993.

Guenther, A., Hewitt, C. N., Erickson, D., Fall, R., Geron, C., Graedel, T., Harley, P., Klinger, L., Lerdau, M., McKay, W. A., Pierce, T., Scholes, B., Steinbrecher, R., Tallamraju, R., Taylor, J., and Zimmermann, P.: A global model of natural volatile organic compound emissions, J. Geophys. Res., 100, 8873-8892, 1995.
Guenther, A.: The contribution of reactive carbon emissions from vegetation to the carbon balance of terrestrial ecosystems, Chemosphere, 49, 837-844, 2002.

Guenther, A., Karl, T., Harley, P., Wiedinmyer, C., Palmer, P. I., and Geron, C.: Estimates of global terrestrial isoprene emissions using MEGAN (Model of Emissions of Gases and Aerosols from Nature), Atmos. Chem. Phys., 6, 3181-3210, 2006, http://www.atmos-chem-phys.net/6/3181/2006/.

Hartz, K. E. H., Rosenorn, T., Ferchak, S. R., Raymond, T. M., Bilde, M., Donahue, N. M., and Pandis, S. N.: Cloud condensation nuclei activation of monoterpene and sesquiterpene secondary organic aerosol, J. Geophys. Res., 110, D14208, doi:14210.11029/12004JD005754, 2005.

Hauglustaine, D. A. and Ehalt, D. H.: A three-dimensional model of molecular hydrogen in the troposphere, J. Geophys. Res., 107, 4330, doi:4310.1029/2001JD001156, 2002.

Hauglustaine, D. A., Lathiere, J., Szopa, S., and Folberth, G. A.: Future tropospheric ozone simulated with a climatechemistry-biosphere model, Geophys. Res. Lett., 32, L24807, doi:24810.21029/22005GL024031, 2005.

Heald, C. L., Wilkinson, M. J., Monson, R. K., Alo, C. A., Wang, G. L., and Guenther, A.: Response of isoprene emission to ambient $\mathrm{CO}_{2}$ changes and implications for global budgets, Glob. Change Biol., 15, 1127-1140, doi:10.1111/j.1365-2486.2008.01802.x, 2009.

Hély, C., Alleaume, S., Swap, R. J., Shugart, H. H., and Justice, C. O.: SAFARI-2000 characterization of fuels, fire behavior, combustion completeness, and emissions from experimental burns in infertile grass savannas in western Zambia, J. Arid Environ., 54, 381-394, 2003.

Henze, D. and Seinfeld, J. H.: Global secondary organic aerosol from isoprene oxidation, Geophys. Res. Lett., 33, L09812, doi:09810.01029/02006GL025976, 2006.

Hickler, T., Smith, B., Sykes, M. T., Davis, M. B., Sugita, S., and Walker, K.: Using a generalized vegetation model to simulate vegetation dynamics in northeastern USA, Ecology, 85, 519530, 2004.

Hickler, T., Smith, B., Prentice, I. C., Mjöfors, K., Miller, P., Arneth, A., and Sykes, M.: $\mathrm{CO}_{2}$ fertilization in temperate face experiments not representative of boreal and tropical forests, Glob. Change Biol., 14, 1-12, doi:10.1111/j.1365-2486.2008.01598.x, 2008.

Hinzman, L. D., Bettez, N. D., Bolton, W. R., Chapin, F. S., Dyurgerov, M. B., Fastie, C. L., Griffith, B., Hollister, R. D., Hope, A., Huntington, H. P., Jensen, A. M., Jia, G. J., Jorgenson, T., Kane, D. L., Klein, D. R., Kofinas, G., Lynch, A. H., Lloyd, A. H., McGuire, A. D., Nelson, F. E., Oechel, W. C., Osterkamp, T. E., Racine, C. H., Romanovsky, V. E., Stone, R. S., Stow, D. A., Sturm, M., Tweedie, C. E., Vourlitis, G. L., Walker, M. D., Walker, D. A., Webber, P. J., Welker, J. M., Winker, K., and Yoshikawa, K.: Evidence and implications of recent climate change in northern Alaska and other arctic regions, Climatic Change, 72, 251-298, 2005.

Hirsch, A. I., Michalak, A. M., Bruhwiler, L. M., Peters, W., Dlugokencky, E. J., and Tans, P. P.: Inverse modeling estimates of the global nitrous oxide surface flux from 1998-2001, Global Biogeochem. Cy., 20, GB1008, doi:1010.1029/2004GB002443, 2006.

Hoelzemann, J. J., Schultz, M., Brasseur, G. P., Granier, C., and Si- 
mon, M.: Global wildland fire emission model (GWEM): Evaluating the use of global area burnt satellite data, J. Geophys. Res., 109, D14S04, doi:10.1029/2003JD003666, 2004.

Hoffmann, T., Odum, J. R., Bowman, F., Collins, D., Klockow, D., Flagan, R. C., and Seinfeld, J. H.: Formation of organic aerosols from the oxidation of biogenic hydrocarbons, J. Atmos. Chem., 26, 189-222, 1997.

Holland, E. A., Dentener, F. J., Braswell, B. H., and Sulzman, J. M.: Contemporary and pre-industrial global reactive nitrogen budgets, Biogeochemistry, 46, 7-43, 1999.

Houghton, R. A.: The annual net flux of carbon to the atmosphere from changes in land use 1850-1990, Tellus B, 51, 298-313, 1999.

Houghton, R. A.: Revised estimates of the annual flux of carbon to the atmosphere from changes in land use and land management 1850-2000, Tellus, 55, 378-390, 2003.

Houweling, S., Röckmann, T., Aben, I., Keppler, F., Krol, M., Meirink, J. F., Dlugokencky, E. J., and Frankenberg, C.: Atmospheric constraints on global emissions of methane from plants, Geophys. Res. Lett., 33, L15821, doi:15810.11029/12006GL026162, 2006.

Huang, Y., Zhang, W., Zheng, X., Han, S., Yu, Y., et al.: Estimates of methane emission from Chinese rice paddies by linking a model to GIS database, Acta Ecol. Sinica, 26, 980-988, 2006.

Hurtt, G. C., Dubayah, R., Drake, J., Moorcroft, P. R., Pacala, S. W., Blair, J. B., and Fearon, M. G.: Beyond potential vegetation: Combining lidar data and a height-structured model for carbon studies, Ecol. Appl., 14, 873-883, 2004.

Imhoff, M. L., Bounoua, L., Ricketts, T., Loucks, C., Harriss, R., and Lawrence, W. T.: Global patterns in human consumption of net primary production, Nature, 429, 870-873, 2004.

Ito, A., Sudo, K., Akimoto, H., Sillman, S., and Penner, J.: Global modeling analysis of tropospheric ozone and its radiative forcing from biomass burning emissions in the twentieth century, J. Geophys. Res., 112, D24307, doi:24310.21029/22007JD008745, 2007.

Jaegle, L., Steinberger, L., Martin, R. V., and Chance, K.: Global partitioning of $\mathrm{NO}_{\mathrm{x}}$ sources using satellite observations: Relative roles of fossil fuel combustion, biomass burning and soil emissions, Faraday Discuss., 130, 407-423, 2005.

Jaegle, L., Martin, R. V., Chance, K., Steinberger, L., Kurosu, T. P., Jacob, D. J., Modi, A. I., Yoboue, V., Sigha-Nkamdjou, L., and Galy-Lacaux, C.: Satellite mapping of rain-induced nitric oxide emissions from soils, J. Geophys. Res., 109(D21), D21310, doi:10.1029/2004JD004787, 2004.

Janssens, I. A. and Luyssaert, S.: Nitrogen's carbon bonus, Nature Geosci., 2(5), 318-319, 2009.

Johnson, E. A.: Fire and vegetation dynamics: Studies from the North American boreal forest, Cambridge University Press, Cambridge, 129 pp., 1992.

Jung, M., Verstraete, M., Gobron, N., Reichstein, M., Papale, D., Bondeau, A., Robustelli, M., and Pinty, B.: Diagnostic assessment of European gross primary production, Glob. Change Biol., 14, 2349-2364, doi:10.1111/j.1365-2486.2008.01647.x, 2008.

Kaplan, J. O.: Wetlands at the last glacial maximum: Distribution and methane emissions, Geophys. Res. Lett., 29, 1079, doi:1010.1029/2001GL013366, 2002.

Kaplan, J. O., Folberth, G., and Hauglustaine, D. A.: Role of methane and biogenic volatile organic compound sources in late glacial and Holocene fluctuations of atmospheric methane concentrations, Global Biogeochem. Cy., 20, GB2016, doi:2010.1929/2005GB002590, 2006.

Karlsson, P. E., Uddling, J., Braun, S., Broadmeadow, M., Elvira, S., Gimeno, B. S., Le Thiec, D., Oksanen, E., Vandermeiren, K., Wilkinson, M., and Emberson, L.: New critical levels for ozone effects on young trees based on AOT40 and simulated cumulative leaf uptake of ozone, Atmos. Environ., 38, 2283-2294, 2004.

Karnosky, D. F.: Impacts of elevated atmospheric $\mathrm{CO}_{2}$ on forest trees and forest ecosystems: Knowledge gaps, Environ. Int., 29, 161-169, 2003.

Karnosky, D. F., Pregitzer, K. S., Zak, D. R., Kubiske, M. E., Hendrey, G. R., Weinstein, D., Nosal, M., and Percy, K. E.: Scaling ozone responses of forest trees to the ecosystem level in a changing climate, Plant Cell Environ., 28, 965-981, 2005.

Kasischke, E. S., Hyer, E. J., Novelli, P. C., Bruhwiler, L. P., French, N. H. F., Sukhinin, A. I., Hewson, J. H., and Stocks, B. J.: Influences of boreal fire emissions on northern hemisphere atmospheric carbon and carbon monoxide, Global Biogeochem. Cy., 19, GB1012, doi:10.1029/2004GB002300, 2005.

Keeling, R. F., Piper, S. C., and Heimann, M.: Global and hemispheric $\mathrm{co}_{2}$ sinks deduced from changes in atmospheric $\mathrm{O}_{2}$ concentration, Nature, 381, 218-221, 1996.

Keller, M., Jacob, D. J., Wofsy, S. C., and Harriss, R. C.: Effects of tropical deforestation on global and regional atmospheric chemistry, Climatic Change, 19, 139-158, 1991.

Keppler, F., Hamilton, J. T. G., Brass, M., and Röckmann, T.: Methane emissions from terrestrial plants under aerobic conditions, Nature, 439, 187-191, doi:10.1038/nature04420, 2006.

Kesik, M., Ambus, P., Baritz, R., Brüggemann, N., ButterbachBahl, K., Damm, M., Duyzer, J., Horváth, L., Kiese, R., Kitzler, B., Leip, A., Li, C., Pihlatie, M., Pilegaard, K., Seufert, S., Simpson, D., Skiba, U., Smiatek, G., Vesala, T., and Zechmeister-Boltenstern, S.: Inventories of $\mathrm{N}_{2} \mathrm{O}$ and $\mathrm{NO}$ emissions from European forest soils, Biogeosciences, 2, 353-375, 2005, http://www.biogeosciences.net/2/353/2005/.

Kesik, M., Bruggemann, N., Forkel, R., Knoche, R., Li, C., Seufert, G., Simpson, D., and Butterbach-Bahl, K.: Future scenarios of $\mathrm{N}_{2} \mathrm{O}$ and $\mathrm{NO}$ emissions from European forest soils, J. Geophys. Res., 111, G02018, doi:02010.01029/02005JG000115, 2006.

Kesselmeier, J. and Staudt, M.: Biogenic volatile organic compounds (VOC): An overview on emission, physiology and ecology, J. Atmos. Chem., 33, 23-88, 1999.

Khalil, M. A. K., Rasmussen, R. A., and Shearer, M. J.: Trends of atmospheric methane during the 1960s and 1970s, J. Geophys. Res.-Atmos., 94, 18279-18288, 1989.

King, G. M. and Crosby, H.: Impacts of plant roots on soil CO cycling and soil-atmosphere $\mathrm{CO}$ exchange, Glob. Change Biol., 8, 1085-1093, 2002.

Kirchhoff, V., Dasilva, I. M. O., and Browell, E. V.: Ozone measurements in Amazonia - dry season versus wet season, J. Geophys. Res.-Atmos., 95, 16913-16926, 1990.

Kothavala, Z., Arain, M. A., Black, T. A., and Verseghy, D.: The simulation of energy, water vapor and carbon dioxide fluxes over common crops by the Canadian land surface scheme (class), Agr. Forest Meteorol., 133, 89-108, 2005.

Krinner, G., Ciais, P., Viovy, N., and Friedlingstein, P.: A simple parameterization of nitrogen limitation on primary productivity for global vegetation models, Biogeosciences 
Discuss., 2, 1243-1282, 2005a, http://www.biogeosciencesdiscuss.net/2/1243/2005/.

Krinner, G., Viovy, N., de Noblet-Ducoudré, N., Ogéé, J., Polcher, J., Friedlingstein, P., Ciais, P., Sitch, S., and Prentice, I. C.: A dynamic global vegetation model for studies of the coupled atmosphere-biosphere system, Global Biogeochem. Cy., 19, GB1015, doi:1010.1029/2003GB002199, 2005b.

Kroeze, C., Mosier, A., and Bouwman, L.: Closing the global $\mathrm{N}_{2} \mathrm{O}$ budget: A retrospective analysis 1500-1994, Global Biogeochem. Cy., 13, 1-8, 1999.

Kroll, J. H., Ng, L. N., Murphy, S. M., Flagan, R. C., and Seinfeld, J. H.: Secondary organic aerosol formation from isoprene photooxidation under high- $\mathrm{NO}_{\mathrm{x}}$ conditions, Geophys. Res. Lett., 32, L18808, doi:10.1029/2005GL023637, 2005.

Kroll, J. H., Ng, N. L., Murphy, S. M., Flagan, R. C., and Seinfeld, J. H.: Secondary organic aerosol formation from isoprene photooxidation, Environ. Sci. Technol., 40, 1869-1877, 2006.

Kucharik, C. J.: Evaluation of a process-based agro-ecosystem model (AGRO-IBIS) across the U.S. corn belt: Simulations of the interannual variability in maize yield, Earth Interactions, 7, 1-33, 2003.

Kucharik, C. J. and Brye, K. R.: Integrated biosphere simulator (IBIS) yield and nitrate loss predictions for Wisconsin maize receiving varied amounts of nitrogen fertilizer, J. Environ. Qual., 32, 247-268, 2003.

Kucharik, C. J. and Twine, T. E.: Residue, respiration, and residuals: Evaluation of a dynamic agroecosystem model using eddy flux measurements and biometric data, Agr. Forest Meteorol., 146, 134-158, 2007.

Kulmala, M.: How particles nucleate and grow, Science, 302, 10001001, 2003.

Kulmala, M., Suni, T., Lehtinen, K. E. J., Dal Maso, M., Boy, M., Reissell, A., Rannik, Ü., Aalto, P., Keronen, P., Hakola, H., Bäck, J., Hoffmann, T., Vesala, T., and Hari, P.: A new feedback mechanism linking forests, aerosols, and climate, Atmos. Chem. Phys., 4, 557-562, 2004, http://www.atmos-chemphys.net/4/557/2004/.

Lal, R.: Soil carbon sequestration impacts on global climate change and food security, Science, 304, 1623-1627, 2004.

Lassey, K. R., Etheridge, D. M., Lowe, D. C., Smith, A. M., and Ferretti, D. F.: Centennial evolution of the atmospheric methane budget: what do the carbon isotopes tell us?, Atmos. Chem. Phys., 7, 2119-2139, 2007, http://www.atmos-chemphys.net/7/2119/2007/.

Lathiére, J., Hauglustaine, D. A., Friend, A. D., De NobletDucoudré, N., Viovy, N., and Folberth, G. A.: Impact of climate variability and land use changes on global biogenic volatile organic compound emissions, Atmos. Chem. Phys., 6, 2129-2146, 2006, http://www.atmos-chem-phys.net/6/2129/2006/.

Lawrence, D. M. and Slater, A. G.: A projection of severe nearsurface permafrost degradation during the 21 st century, Geophys. Res. Lett., 32, L24401, doi:24410.21029/22005GL025080, 2005.

Lelieveld, J., Crutzen, P. J., and Dentener, F. J.: Changing concentration, lifetime and climate forcing of atmospheric methane, Tellus B, 50, 128-150, 1998.

Lelieveld, J., Butler, T. M., Crowley, J. N., Dillon, T. J., Fischer, H., Ganzeveld, L., Harder, H., Lawrence, M. G., Martinez, M., Taraborrelli, D., and Williams, J.: Atmospheric oxidation capac- ity sustained by a tropical forest, Nature, 452, 737-740, 2008.

Lenihan, J. M. and Neilson, R. P.: Simulating broad-scale fire severity in a dynamic global vegetation model, Northwest Science, 72, 91-103, 1998.

Lerdau, M.: A positive feedback with negative consequences, Science, 316, 212-213, doi:210.1126/science.1141486, 2007.

Levis, S., Foley, J. A., and Pollard, D.: Large-scale vegetation feedbacks on a doubled $\mathrm{CO}_{2}$ climate, J. Climate, 13, 1313-1325, 2000.

Li, C., Aber, J., Stange, F., Butterbach-Bahl, K., and Papen, H.: A process-oriented model of $\mathrm{N}_{2} \mathrm{O}$ and $\mathrm{NO}$ emissions from forest soils: 1. Model development, J. Geophys. Res., 105, 4369-4384, 2000.

Li, C., Mosier, A., Wassmann, R., Cai, Z., Zheng, X., Huang, Y., Tsuruta, H., Boonjawat, J., and Lantin, R.: Modeling greenhouse gas emissions from rice-based ecosystems: Sensitivity and upscaling, Global Biogeochem. Cy., 18, GB1043, doi:1010.1029/2003GB002045, 2004.

Li, C., Frolking, S., and Butterbach-Bahl, K.: Carbon sequestration can increase nitrous oxide emissions, Climatic Change, 72, 321338, 2005.

Liao, H., Cheng, W.-T., and Seinfeld, J. H.: Role of climate change in global predictions of future tropospheric ozone and aerosols, J. Geophys. Res., 111, D12304, doi:12310.11029/12005JD006852, 2006.

Lichtenthaler, H. K., Rohmer, M., and Schwender, J.: Two independent biochemical pathways for isopentenyl diphosphate and isoprenoid biosynthesis in higher plants, Physiologia Plantarum, 101, 643-652, 1997.

Lobell, D. B., Bala, G., and Duffy, P. B.: Biogeophysical impacts of cropland management changes on climate, Geophys. Res. Lett., 33, L06708, doi:06710.01029/02005GL025492, 2006.

Lobell, D. B., Burke, M. B., Tebaldi, C., Mastrandrea, M. D., Falcon, W. P., and Naylor, R. L.: Prioritizing climate change adaptation needs for food security in 2030, Science, 319, 607-610, 2008.

Long, S. P., Ainsworth, E. A., Leakey, A. D. B., Nosberger, J., and Ort, D. R.: Food for thought: Lower-than-expected crop yield stimulation with rising $\mathrm{CO}_{2}$ concentrations, Science, 312, 1918 1921, 2006.

Loreto, F. and Velikova, V.: Isoprene produced by leaves protects the photosynthetic apparatus against ozone damage, quenches ozone products, and reduces lipid peroxidation of cellular membranes, Plant Physiol., 127, 1781-1787, 2001.

Lotze-Campen, H., Lucht, W., Müller, C., Bondeau, A., and Smith, P.: How tight are the limits to land and water use? - Combined impacts of food demand and climate change, Adv. Geosci., 4, 23-28, 2005, http://www.adv-geosci.net/4/23/2005/.

Martin, R. E., Asner, G. P., Ansley, R. J., and Mosier, A. R.: Effects of woody vegetation encroachment on soil nitrogen oxide emissions in a temperate savanna, Ecol. Appl. 13, 897-910, 2003.

McGuire, A. D., Sitch, S., Clein, J. S., Dargaville, R., Esser, G., Foley, J., Heimann, M., Joos, F., Kaplan, J., Kicklighter, D. W., Meier, R. A., Melillo, J. M., Moore III, B., Prentice, I. C., Ramankutty, N., Reichenau, T., Schloss, A., Tian, H., Williams, L. J., and Wittenberg, U.: Carbon balance of the terrestrial biosphere in the twentieth century: Analysis of $\mathrm{co}_{2}$, climate and land use effects with four process-based ecosystem models, Global Biogeochem. Cy., 15, 183-206, 2001. 
McLaughlin, S. B., Nosal, M., Wullschleger, S. D., and Sun, G.: Interactive effects of ozone and climate on tree growth and water use in a southern Appalachian forest in the USA, New Phytol., 174, 109-124, 2007.

Meijer, E. W., van Velthoven, P. F. J., Brunner, D. W., Huntrieser, H., and Kelder, H.: Improvement and evaluation of the parameterisation of nitrogen oxide production by lightning, Phys. Chem. Earth C, 26, 577-583, 2001.

Melillo, J. M., Steudler, P. A., Feigl, B. J., Neill, C., Garcia, D., Picollo, M. C., Cerri, C. C., and Tian, H.: Nitrous oxide emissions from forests and pastures of various ages in the Brazilian Amazon, J. Geophys. Res., 106, 34179-34188, 2001.

Mickley, L. J., Jacob, D., and Rind, D.: Uncertainty in preindustrial abundance of tropospheric ozone: Implications for radiative forcing calculations, J. Geophys. Res., 106, 3389-3399, 2001.

Mikaloff Fletcher, S. E., Tans, P. P., Bruhwiler, L. M., Miller, J. B., and Heimann, M.: $\mathrm{CH}_{4}$ sources estimated from atmospheric observations of $\mathrm{ch}_{4}$ and its c-13/c-12 isotopic ratios: 1 . Inverse modeling of source processes, Global Biogeochem. Cy., 18, GB4004, doi:4010.1029/2004GB002223, 2004a.

Mikaloff Fletcher, S. E., Tans, P. P., Bruhwiler, L. M., Miller, J. B., and Heimann, M.: CH4 sources estimated from atmospheric observations of $\mathrm{CH}_{4}$ and its $\mathrm{C}-13 / \mathrm{C}-12$ isotopic ratios: 2 . Inverse modeling of $\mathrm{CH}_{4}$ fluxes from geographical regions, Global Biogeochem. Cy., 18, GB4005, doi:4010.1029/2004GB002224, 2004b.

Miller, P. A., Giesecke, T., Hickler, T., Bradshaw, R. H. W., Smith, B., Seppä, H., and Sykes, M. T.: Exploring climatic and biotic controls on Holocene vegetation change in Fennoscandia, J. Ecol., 247-259, doi:210.1111/j.1365-2745.2007.01342.x, 2008.

Monson, R. K. and Holland, E.: Biospheric trace gas fluxes and their control over tropospheric chemistry, Annu. Rev. Ecol. Syst., 32, 547-576, 2001.

Moorcroft, P. R., Hurtt, G. C., and Pacala, S. W.: A method for scaling vegetation dynamics: The ecosystem demography model (ed.), Ecol. Monogr., 71, 557-586, 2001.

Muller, C., Bondeau, A., Lotze-Campen, H., Cramer, W., and Lucht, W.: Comparative impact of climatic and nonclimatic factors on global terrestrial carbon and water cycles, Global Biogeochem. Cy., 20, GB4015, doi:4010.1029/2006GB002742, 2006.

Muller, C., Eickhout, B., Zaehle, S., Bondeau, A., Cramer, W., and Lucht, W.: Effects of changes in $\mathrm{CO}_{2}$, climate, and land use on the carbon balance of the land biosphere during the 21 st century, J. Geophys. Res.-Biogeosci., 112, G02032, doi:02010.01029/02006JG000388, 2007.

Naik, V., Maurzerall, D. L., Horowitz, L. W., Schwarzkopf, M. D., Ramaswamy, V., and Oppenheimer, M.: On the sensitivity of radiative forcing from biomass burning aerosols and ozone to emission location, Geophys. Res. Lett., 34, L03818, doi:03810.01029/02006GL028149, 2007.

Neff, J. C., Keller, M., Holland, E. A., Weitz, A., and Veldkamp, E.: Fluxes of nitric oxide from soils following the clearing and burning of a secondary tropical rain forest, J. Geophys. Res.-Atmos., 100(D12) 25913-25922, 1995.

Nesterov, V. G.: Gorimost' lesa i metody eio opredelenia, Goslesbumaga, Moscow, 1949.

Nevison, C. D., Mahowald, N. M., Weiss, R. F., and Prinn, R. G.: Interannual and seasonal variability in atmospheric $\mathrm{N}_{2} \mathrm{O}$, Global
Biogeochem. Cy., 21, GB3017, doi:3010.1029/2006GB002755, 2007.

Ng, N. L., Chhabra, P. S., Chan, A. W. H., Surratt, J. D., Kroll, J. H., Kwan, A. J., McCabe, D. C., Wennberg, P. O., Sorooshian, A., Murphy, S. M., Dalleska, N. F., Flagan, R. C., and Seinfeld, J. H.: Effect of $\mathrm{NO}_{\mathrm{x}}$ level on secondary organic aerosol (SOA) formation from the photooxidation of terpenes, Atmos. Chem. Phys., 7, 5159-5174, 2007, http://www.atmos-chemphys.net/7/5159/2007/.

Niinemets, U., Tenhunen, J. D., Harley, P. C., and Steinbrecher, R.: A model of isoprene emission based on energetic requirements for isoprene synthesis and leaf photosynthetic properties for Liquidambar and Quercus, Plant Cell Environ., 22, 13191335, 1999.

Novelli, P. C., Lang, P. M., Masarie, K. A., Hurst, D. F., Myers, R., and Elkins, J. W.: Molecular hydrogen in the troposphere: Global distribution and budget, J. Geophys. Res., 104, 3042730444, 1999.

Olofsson, J. and Hickler, T.: Effects of human land-use on the global carbon cycle during the last 6000 years, Vegetation History and Archeobotany, 17(5), 605-615, doi:10.1007/s00334007-0126-6, 2007.

Osborne, T. M., Lawrence, D. M., Challinor, A. J., Slingo, J. M., and Wheeler, T. R.: Development and assessment of a coupled crop-climate model, Glob. Change Biol., 13, 169-183, 2007.

Palmer, P. I., Jacob, D. J., Fiore, A. M., Martin, R. V., Chance, K., and Kurosu, T. P.: Mapping isoprene emissions over North America using formaldehyde column observations from space, J. Geophys. Res., 108, 4180, doi:10.1029/2002JD002153, 2003.

Parry, M., Rosenzweig, C., Iglesias, A., Fischer, G., and Livermore, M.: Climate change and world food security: A new assessment, Global Environ. Chang., 9, S51-S67, 1999.

Parton, W. J., Mosier, A. R., Ojima, D. S., Valentine, D. W., Schimel, D. S., Weier, K., and Kulmala, A. E.: Generalized model for N-2 and N2O production from nitrification and denitrification, Global Biogeochem. Cy., 10, 401-412, 1996.

Parton, W. J., Holland, E. A., Del Grosso, S. J., Hartman, M. D., Martin, R. E., Mosier, A. R., Ojima, D. S., and Schimel, D. S.: Generalized model for $\mathrm{NO}_{\mathrm{X}}$ and $\mathrm{N}_{2} \mathrm{O}$ emissions from soils, J. Geophys. Res.-Atmos., 106, 17403-17419, 2001.

Paungfoo-Lonhienne, C., Lonhienne, T. G. A., Rentsch, D., Robinson, N., Christie, M., Webb, R. I., Gamage, H. K., Carroll, B. J., Schenk, P. M., and Schmidt, S.: Plants can use protein as a nitrogen source without assistance from other organisms, P. Natl. Acad. Sc. USA, 105, 4524-4529, 2008.

Pegoraro, E., Rey, A., Barron-Gafford, G., Monson, R., Malhi, Y., and Murthy, R.: The interacting effects of elevated atmospheric $\mathrm{CO}_{2}$ concentration, drought and leaf-to-air vapour pressure deficit on ecosystem isoprene fluxes, Oecologia, 146, 120129, doi:110.1007/s00442-00005-00166-00445, 2005.

Penuelas, J. and Llusia, J.: Plant voc emissions: Making use of the unavoidable, Trends Ecol. Evol., 19, 402-404, 2004.

Pfeiffer, T., Forberich, O., and Comes, F. J.: Tropospheric OH formation by ozonolysis of terpenes, Chem. Phys. Lett., 298, 351358, 1998.

Pielke, R. A. S., Avissar, R., Raupach, M., Dolmann, A. J., Zeng, X., and Denning, A. S.: Interactions between the atmosphere and terrestrial ecosystems: Influence on weather and climate, Glob. Change Biol., 4, 461-475, 1998. 
Pierce, T., Geron, C., Bender, L., Dennis, R., Tonnesen, G., and Guenther, A.: Influence of increased isoprene emissions on regional ozone modeling, J. Geophys. Res., 103, 25611-25629, 1998.

Pilegaard, K., Skiba, U., Ambus, P., Beier, C., Brüggemann, N., Butterbach-Bahl, K., Dick, J., Dorsey, J., Duyzer, J., Gallagher, M., Gasche, R., Horvath, L., Kitzler, B., Leip, A., Pihlatie, M. K., Rosenkranz, P., Seufert, G., Vesala, T., Westrate, H., and Zechmeister-Boltenstern, S.: Factors controlling regional differences in forest soil emission of nitrogen oxides ( $\mathrm{NO}$ and $\mathrm{N}_{2} \mathrm{O}$ ), Biogeosciences, 3, 651-661, 2006, http://www.biogeosciences.net/3/651/2006/.

Pleijel, H., Danielsson, H., Ojanpera, K., De Temmerman, L., Hogy, P., Badiani, M., and Karlsson, P. E.: Relationships between ozone exposure and yield loss in European wheat and potato a comparison of concentration- and flux-based exposure indices, Atmos. Environ., 38, 2259-2269, 2004.

Plöchl, M., Lyons, T., Ollerenshaw, J., and Barnes, J.: Simulating ozone detoxification in the leaf apoplast through the direct reaction with ascorbate, Planta, 210, 454-467, 2000.

Possell, M., Hewitt, N. C., and Beerling, D. J.: The effects of glacial atmospheric $\mathrm{CO}_{2}$ concentrations and climate on isoprene emissions by vascular plants, Glob. Change Biol., 11, 60-69, 2005.

Potter, C. S., Klooster, S. A., and Chatfield, R. B.: Consumption and production of carbon monoxide in soils: A global model analysis of spatial and seasonal variation, Chemosphere, 33, 1175-1193, 1996.

Potter, C. S. and Klooster, S. A.: Interannual variability in soil trace gas $\left(\mathrm{CO}_{2}, \mathrm{~N}_{2} \mathrm{O}, \mathrm{NO}\right)$ fluxes and analysis of controllers on regional to global scales, Global Biogeochem. Cy., 12, 621-635, 1998.

Potter, C., Klooster, S., and Krauter, C.: Regional modeling of ammonia emissions from native soil sources in California, Earth Interactions, 7, 1-28, doi:10.1175/10873562(2003)007;0001:RMOAEF i2.0.CO;2, 2003.

Prather, M., Ehhalt, D., Dentener, F. J., Derwent, R., Dlugokencky, E. J., Holland, E., Isaksen, I., Katima, J., Kirchhoff, V., Matson, P., Midgley, P., M., W., et al.: Atmospheric chemistry and greenhouse gases, in: Climate change 2001. The scientific basis. Contribution of working group I to the Third Assessment Report of the Intergovernmental Panel on Climate Change, edited by: Houghton, J. T., Ding, Y., Griggs, D. J., Noguer, M., van der Linden, P. J., Dai, X., Maskell, K., and Johnson, C. A., University Press, Cambridge, 238-287, 2001.

Prentice, I. C., Heimann, M., and Sitch, S.: The carbon balance of the terrestrial biosphere: Ecosystem models and atmospheric observations, Ecol. Appl., 10, 1553-1573, 2000.

Prentice, I. C., Bondeau, A., Cramer, W., Harrison, S. P., Hickler, T., Lucht, W., Sitch, S., Smith, B., and Sykes, M. T.: Dynamic global vegetation modelling: Quantifying terrestrial ecosystem responses to large-scale environmental change, in: Terrestrial ecosystems in a changing world, edited by: Canadell, J. G., Pataki, D. E., and Pitelka, L. F., IGBP series, Heidelberg, Berlin, 175-192, 2007.

Price, H., Jaegle, L., Rice, A., Quay, P., Novelli, P. C., and Gammon, R.: Global budget of molecular hydrogen and its deuterium content: Constraints from ground station, cruise, and aircraft observations, J. Geophys. Res., 1611-1625, D22108, doi:10.1029/2006JD008152, 2007.
Prigent, C., Matthews, E., Aires, F., and Rossow, W. B.: Remote sensing of global wetland dynamics with multiple satellite data sets, Geophys. Res. Lett., 28, 4631-4634, 2001.

Prinn, R. G., Weiss, R. F., Fraser, P. J., Simmonds, P. G., Cunnold, D. M., Alyea, F. N., O’Doherty, S., Salameh, P., Miller, B. R., Huang, J., Wang, R. H. J., Hartley, D. E., Harth, C., Steele, L. P., Sturrock, G., Midgley, P. M., and McCulloch, A.: A history of chemically and radiatively important gases in air deduced from ALE/GAGE/AGAGE, J. Geophys. Res., 105, 17751-17792, 2000.

Pye, H. O. T., Liao, H., Wu, S., Mickley, L. J., Jacob, D. J., Henze, D. K., and Seinfeld, J. H.: Effect of changes in climate and emissions on future sulfate-nitrate-ammonium aerosol levels in the United States, J. Geophys. Res., 114, D01205, doi:10.1029/2008JD010701, 2009.

Pyne, S. J.: World fire. Cycle of fire, Henry Holt and Company, New York, 379 pp., 1995.

Raynaud, D., Barnola, J. M., Chappellaz, J., Blunier, T., Indermuhle, A., and Stauffer, B.: The ice record of greenhouse gases: A view in the context of future changes, Quaternary Sci. Rev., 19, 9-17, 2000.

Reich, P. B.: Quantifying plant response to ozone: A unifying theory, Tree Physiol., 3, 63-91, 1987.

Reilly, J. M. and Schimmelpfenning, D.: Agricultural impact assessment, vulnerability, and the scope for adaptation, Climatic Change, 43, 745-788, 1999.

Ren, W., Tian, H., Chen, G., Liu, M., Zhang, C., Chappelka, A. H., and Pan, S.: Influence of ozone pollution and climate variability on net primary productivity and carbon storage in China's grassland ecosystems from 1961 to 2000, Environ. Pollut., 149, 327-335, 2007.

Rhee, T. S., Brenninkmeijer, C. A. M., and Röckmann, T.: The overwhelming role of soils in the global atmospheric hydrogen cycle, Atmos. Chem. Phys., 6, 1611-1625, 2006, http://www.atmoschem-phys.net/6/1611/2006/.

Riemer, N., Vogel H., Vogel B., Schell B., Ackermann I., Kessler C., and Hass H.: Impact of the heterogeneous hydrolysis of $\mathrm{N}_{2} \mathrm{O}_{5}$ on chemistry and nitrate aerosol formation in the lower troposphere under photosmog conditions, J. Geophys. Res., 108, 4144, doi:10.1029/2002JD002436, 2003.

Rigolot, E.: Predicting postfire mortality of Pinus halepensis Mill. and Pinus pinea L., Plant Ecol., 171, 139-151, 2004.

Rinne, J., Riutta, T., Pihlatie, M., Aurela, M., Haapanala, S., Tuovinen, J. P., Tuittila, E. S., and Vesala, T.: Annual cycle of methane emission from a boreal fen measured by the eddy covariance technique, Tellus B-, 59, 449-457, 2007.

Roberts, N.: The Holocene, 2nd ed., Blackwell Publising, Oxford, 316 pp., 1989.

Rosenstiel, T. N., Potosnak, M. J., Griffin, K. L., Fall, R., and Monson, R. K.: Increased $\mathrm{CO}_{2}$ uncouples growth from isoprene emission in an agriforest ecosystem, Nature, 421, 256259, doi:10.1038/nature01312, 2003.

Rosenzweig, C., Parry, M. L., Fischer, G., Frohberg, K., et al.: Climate change on world food supply, University of Oxford, Oxford, 1993.

Rosenzweig, C. and Iglesias, A.: Potential impacts of climate change on world food supply. Data sets from a major crops modeling study, CIESIN Columbia University, 2001.

Rost, S., Gerten, D., Bondeau, A., Lucht, W., Rohwer, J., and 
Schaphoff, S.: Agriculture green and blue water consumption and its influence on the global water system, Water Resour. Res., 44, B06303, doi:10.1029/2007JB005263, 2008.

Rothermel, R. C.: A mathematical model for predicting fire spread in wildland fuels, Odgen, USA, 1972.

Roulet, N., Moore, T., Bubier, J., and Lafleur, P.: Northern fens methane flux and climatic change, Tellus B, 44, 100-105, 1992.

Saarnio, S., Almu, J., Silvola, J., Lohila, A., Nykanen, H., and Martikainen, P. J.: Seasonal variation in $\mathrm{CH}_{4}$ emissions and production and oxidation potentials at microsites on an oligotrophic pine fen, Oecologia, 110, 414-422, 1997.

Sanderson, M. G.: Emissions of carbon monoxide by vegetation and soils, Hadley Centre Technical Note 36, 2002.

Sanderson, M. G., Jones, C. D., Collins, W. J., Johnson, C. E., and Derwent, R. G.: Effect of climate change on isoprene emissions and surface ozone levels, Geophys. Res. Lett., 30, 1936, doi:1910.1029/2003GL017642, 2003a.

Sanderson, M. G., Collins, W. J., Derwent, R. G., and Johnson, C. E.: Simulation of global hydrogen levels using a Lagrangian three-dimensional model, J. Atmos. Chem., 46, 15-28, $2003 \mathrm{~b}$.

Sanderson, M. G., Collins, W. J., Hemming, D. L., and Betts, R. A.: Stomatal conductance changes due to increasing carbon dioxide levels: Projected impact on surface ozone levels, Tellus B, 59, 404-411, doi:10.1111/j.1600-0889.2007.00277.x, 2007.

Schimel, J. P. and Bennett, J.: Nitrogen mineralization: Challenges of a changing paradigm, Ecology, 85, 591-602, 2004.

Schindlbacher, A., Zechmeister-Boltenstern, S., and ButterbachBahl, K.: Effects of soil moisture and temperature on $\mathrm{NO}, \mathrm{NO}_{2}$, and $\mathrm{N}_{2} \mathrm{O}$ emissions from European forest soils, J. Geophys. Res., 109, D17302, doi:10.1029/2004JD004590, 2004.

Schröter, D., Cramer, W., Leemans, R., Prentice, I. C., Araujo, M. B., Arnell, N., Bondeau, A., et al.: Ecosystem service supply and vulnerability to global change in Europe, Science, 310, 13331337, 2005.

Schultz, M. G., Diehl, T., Brasseur, G. P., and Zittel, W.: Air pollution and climate-forcing impacts of a global hydrogen economy, Science, 302, 624-627, doi:10.1126/science.1089527, 2003.

Schumann, U. and Huntrieser, H.: The global lightning-induced nitrogen oxides source, Atmos. Chem. Phys., 7, 3823-3907, 2007, http://www.atmos-chem-phys.net/7/3823/2007/.

Schurgers, G., Arneth, A., Holzinger, R., and Goldstein, A. H.: Process-based modelling of biogenic monoterpene emissions combining production and release from storage, Atmos. Chem. Phys., 9, 3409-3423, 2009, http://www.atmos-chemphys.net/9/3409/2009/.

Seiler, W. and Crutzen, P. J.: Estimates of gross and net fluxes of carbon between the biosphere and the atmosphere from biomass burning, Climatic Change, 2, 207-247, 1980.

Seiler, W. and Conrad, R.: Contribution of tropical ecosystems to the global budgets for trace gases, especially $\mathrm{CH}_{4}, \mathrm{H}_{2}, \mathrm{CO}$ and $\mathrm{N}_{2} \mathrm{O}$, in: The geophysiology of Amazonia: Vegetation and climate interactions, edited by: Dickerson, R. E., John Wiley, New York, 33-62, 1987.

Seitzinger, S. P., Harrison, J., Bohlke, J., Bouwman, A., Lowrance, R., Peterson, B., Tobias, C., and Van Drecht, G.: Denitrification across landscapes and waterscapes: A synthesis, Ecol. Appl., 16, 2064-2090, 2006.

Serreze, M. C., Bromwich, D. H., Clark, M. P., Etringer, A. J., Zhang, T. J., and Lammers, R.: Large-scale hydro-climatology of the terrestrial arctic drainage system, J. Geophys. Res., 108, 8160, doi:10.1029/2001JD000919, 2002.

Severinghaus, J. P., Sowers, T., Brook, E. J., Alley, R. B., and Bender, M. L.: Timing of abrupt climate change at the end of the younger Dryas interval from thermally fractionated gases in polar ice, Nature, 391, 141-146, 1998.

Sitch, S., Smith, B., Prentice, I. C., Arneth, A., Bondeau, A., Cramer, W., Kaplan, J. O., Levis, S., Lucht, W., Sykes, M. T., Thonicke, K., and Venevsky, S.: Evaluation of ecosystem dynamics, plant geography and terrestrial carbon cycling in the LPJ dynamic global vegetation model, Glob. Change Biol., 9, 161185, 2003.

Sitch, S., Brovkin, V., von Bloh, W., van Vuuren, D., Assessment, B., and Ganopolski, A.: Impacts of future land cover changes on atmospheric $\mathrm{CO}_{2}$ and climate, Global Biogeochem. Cy., 19, GB2013, doi:2010.1029/2004GB002311, 2005.

Sitch, S., Cox, P. M., Collins, W. J., and Huntingford, C.: Indirect radiative forcing of climate change through ozone effects on the land-carbon sink, Nature, 448(7155), 791-794, doi:710.1038/nature06059, 2007.

Sitch, S., Huntingford, C., Gedney, N., Levy, P. E., Lomas, M., Piao, S., Betts, R., Ciais, P., Cox, P., Friedlingstein, P., Jones, C. D., Prentice, I. C., and Woodward, F. I.: Evaluation of the terrestrial carbon cycle, future plant geography, and climate-carbon cycle feedbacks using 5 dynamic global vegetation models (DGVMs), Glob. Change Biol., 14, 2015-2039, doi:10.1111/j.1365-2486.2008.01626.x, 2008.

Six, J., Ogle, S. M., Breidt, F. J., Conant, R. T., Mosier, A. R., and Paustian, K.: The potential to mitigate global warming with notillage management is only realized when practiced in the long term, Glob. Change Biol., 10, 155-160, 2004.

Smith-Downey, N. V., Randerson, J. T., and Eiler, J. M.: Temperature and moisture dependence of soil $\mathrm{H}_{2}$ uptake measured in the laboratory, Geophys. Res. Lett., 33, L14813, doi:14810.11029/12006GL026749, 2006.

Smith, B., Prentice, I. C., and Sykes, M. T.: Representation of vegetation dynamics in the modelling of terrestrial ecosystems: Comparing two contrasting approaches within European climate space, Glob. Ecol. Biogeogr., 10, 621-637, 2001.

Smith, K. A. and Conen, F.: Impacts of land management on fluxes of trace greenhouse gases, Land Use Management, 20, 255-263, 2004.

Sokolov, A. P., Kicklighter, D. W., Melillo, J. M., Felzer, B. S., Schlosser, C. A., and Cronin, T. W.: Consequences of considering carbon-nitrogen interactions on the feedbacks between climate and the terrestrial carbon cycle, J. Climate, 21, 3776-3796, 2008.

Soussana, J. F., Loiseau, P., Vuichard, N., Ceschia, E., Balesdent, J., Chevallier, T., and Arrouays, D.: Carbon cycling and sequestration opportunities in temperate grasslands, Soil Use and Management, 20, 219-230, 2004.

Spracklen, D. V., Bonn, B., and Carslaw, K.: Boreal forests, aerosols and the impacts on clouds and climate, Philos. T. Roy. Soc. London A, 366, 4613-4626, doi:4610.1098/rsta.2008.0201, 2008.

Staudt, M. and Seufert, G.: Light-dependent emission of monoterpenes by holm oak (Quercus ilex 1.), Naturwissenschaften, 82, 89-92, 1995.

Stehfest, E. and Bouwman, L.: $\mathrm{N}_{2} \mathrm{O}$ and $\mathrm{NO}$ emission from agri- 
cultural fields and soils under natural vegetation: Summarizing available measurement data and modeling of global annual emissions, Nutrient Cycling in Agroecosystems, 74, 207-228, 2006.

Stehfest, E., Heistermann, M., Priess, J. A., Ojima, D. S., and Alcamo, J.: Simulation of global crop production with the ecosystem model DayCent, Ecol. Modell., 209, 203-219, doi:10.1016/j.ecolmodel.2007.06.028, 2007.

Stephens, S. L. and Finney, M. A.: Prescribed fire mortality of sierra nevada mixed conifer tree species: Effects of crown damage and forest floor combustion, Forest Ecol. Manage., 162, 261-271, 2002.

Stevenson, D. S., Dentener, F. J., Schultz, M. G., Ellingsen, K., van Noije, T. P. C., Wild, O., Zeng, G., Amann, M., Atherton, C. S., et al.: Multi-model ensemble simulations of present-day and near-future tropospheric ozone, J. Geophys. Res., 111, D08301, doi:08310.01029/02005JD006338, 2006.

Tan, G. and Shibasaki, R.: Global estimation of crop productivity and the impacts of global warming by GIS and epic integration, Ecol. Modell., 168, 357-370, 2003.

Thonicke, K., Prentice, I. C., and Hewitt, C.: Modeling glacial-interglacial changes in global fire regimes and trace gas emissions, Global Biogeochem. Cy., 19, GB3008, doi:10.1029/2004GB002278, 2005.

Thonicke, K., Spessa, A., Prentice, I. C., Harrison, S. P., Dong, L., and Carmona-Moreno, C.: The influence of vegetation, fire spread and fire behaviour on biomass burning and trace gas emissions: results from a process-based model, Biogeosciences, in review, 2009.

Thornton, P. E., Law, B. E., Gholz, H. L., Clark, K. L., Falge, E., Ellsworth, D. S., Golstein, A. H., Monson, R. K., Hollinger, D., Falk, M., Chen, J., and Sparks, J. P.: Modeling and measuring the effects of disturbance history and climate on carbon and water budgets in evergreen needleleaf forests, Agr. Forest Meteorol., 113, 185-222, 2002.

Thornton, P. E., Lamarque, J.-F., Rosenbloom, N. A., and Mahowald, N. M.: Influence of carbon-nitrogen cycle coupling on land model response to $\mathrm{CO}_{2}$ fertilization and climate variability, Global Biogeochem. Cy., 21, GB4018, doi:4010.1029/2006GB002868, 2007.

Thornton, P. E., Doney, S. C., Lindsay, K., Moore, J. K., Mahowald, N., Randerson, J. T., Fung, I., Lamarque, J.-F., Feddema, J. J., and Lee, Y.-H.: Carbon-nitrogen interactions regulate climate-carbon cycle feedbacks: results from an atmosphereocean general circulation model, Biogeosciences, 6, 2099-2120, 2009, http://www.biogeosciences.net/6/2099/2009/.

Tie, X., Emmons, L., Horowitz, L., Brasseur, G., et al.: Effect of sulfate aerosol on tropospheric $\mathrm{NO}_{\mathrm{x}}$ and ozone budgets: Model simulations and TOPSE evidence, J. Geophys. Res., 108, 8364, doi:10.1029/2001JD001508, 2003.

Tsigaridis, K., Lathiére, J., Kanakidou, M., and Hauglustaine, D. A.: Naturally driven variability in the global secondary organic aerosol over a decade, Atmos. Chem. Phys., 5, 1891-1904, 2005, http://www.atmos-chem-phys.net/5/1891/2005/.

Tsigaridis, K. and Kanakidou, M.: Global modelling of secondary organic aerosol in the troposphere: a sensitivity analysis, Atmos. Chem. Phys., 3, 1849-1869, 2003, http://www.atmos-chemphys.net/3/1849/2003/.

Tsigaridis, K. and Kanakidou, M.: Secondary organic aerosol importance in the future atmosphere, Atmos. Environ., 41, 4682-
4692, 2007.

Tunved, P., Hansson, H. C., Kerminen, V. M., Strom, J., Maso, M. D., Lihavainen, H., Viisanen, Y., Aalto, P. P., Komppula, M., and Kulmala, M.: High natural aerosol loading over boreal forests, Science, 312, 261-263, doi:10.1126/science.1123052, 2006.

Twine, T. E., Kucharik, C. J., and Foley, J. A.: Effects of land cover change on the energy and water balance of the Mississippi river basin, J. Hydrometeorol., 5, 640-655, 2004.

Valdes, P. J., Beerling, D. J., and Johnson, D. E.: The ice age methane budget, Geophys. Res. Lett., 32, L02704, doi:02710.01029/02004GL021004, 2005.

van der Werf, G. R., Randerson, J. T., Collatz, G. J., Giglio, L., Kasibhatla, P. S., Arellano Jr., A. F., Olsen, S. C., and Kasischke, E. S.: Continental-sale partitioning of fire emissions during the 1997 to $2001 \mathrm{El}$ Nino/La Nina period, Science, 303, 73-76, doi:10.1126/science.1090753, 2004.

van der Werf, G. R., Randerson, J. T., Giglio, L., Collatz, G. J., Kasibhatla, P. S., and Arellano Jr., A. F.: Interannual variability in global biomass burning emissions from 1997 to 2004, Atmos. Chem. Phys., 6, 3423-3441, 2006, http://www.atmoschem-phys.net/6/3423/2006/.

VanReken, T. M., Ng, N. L., Flagan, R. C., and Seinfeld, J. H.: Cloud condensation nucleus activation properties of biogenic secondary organic aerosol, J. Geophys. Res., 110, D07206, doi:10.1029/2004JD005465, 2005.

Venevsky, S.: Broad-scale vegetation dynamics in north-eastern Eurasia - observations and simulations, Institut fuer Bodenkultur, Univerisity of Vienna, Vienna, 2001.

Vetter, M., Churkina, G., Jung, M., Reichstein, M., Zaehle, S., Bondeau, A., Chen, Y., Ciais, P., Feser, F., Freibauer, A., Geyer, R., Jones, C., Papale, D., Tenhunen, J., Tomelleri, E., Trusilova, K., Viovy, N., and Heimann, M.: Analyzing the causes and spatial pattern of the European 2003 carbon flux anomaly using seven models, Biogeosciences, 5, 561-583, 2008, http://www.biogeosciences.net/5/561/2008/.

Vigano, I., van Weelden, H., Holzinger, R., Keppler, F., McLeod, A., and Röckmann, T.: Effect of UV radiation and temperature on the emission of methane from plant biomass and structural components, Biogeosciences, 5, 937-947, 2008, http://www.biogeosciences.net/5/937/2008/.

Vitousek, P. M., Ehrlich, P. R., Ehrlich, A. H., and Matson, P. A.: Human appropriation of the products of photosynthesis, Bioscience, 36, 368-373, 1986.

Volk, M., Bungener, P., Contat, F., Montani, M., and Fuhrer, J.: Grassland yield declined by a quarter in 5 years of free-air ozone fumigation, Glob. Change Biol., 12, 74-83, 2006.

von Kuhlmann, R., Lawrence, M. G., Pöschl, U., and Crutzen, P. J.: Sensitivities in global scale modeling of isoprene, Atmos. Chem. Phys., 4, 1-17, 2004, http://www.atmos-chemphys.net/4/1/2004/.

Voulgarakis, A., Wild, O., Savage, N. H., Carver, G. D., and Pyle, J. A.: Clouds, photolysis and regional tropospheric ozone budgets, Atmos. Chem. Phys., 9, 8235-8246, 2009, http://www.atmoschem-phys.net/9/8235/2009/.

Walter, B., Heimann, M., and Matthews, E.: Modeling modern methane emissions from natural wetlands 1 . Model description and results, J. Geophys. Res., 106, 34189-34206, 2001.

Wang, J. S., Logan, J. A., McElroy, M. B., Duncan, B. N., Megretskaia, I. A., and Yantosca, R. M.: A 3-d model analysis of 
the slowdown and interannual variability in the methane growth rate from 1988 to 1997, Global Biogeochem. Cy., 18, GB3011, doi:3010.1029/2003GB002180, 2004.

Wang, K. Y. and Shallcross, D. E.: Modelling terrestrial biogenic isoprene fluxes and their potential impact on global chemical species using a coupled LSM-CTM model, Atmos. Environ., 34, 2909-2925, 2000.

Wang, Y. H., Jacob, D. J., and Logan, J. A.: Global simulation of tropospheric O-3-NOx-Hydrocarbon chemistry 3. Origin of tropospheric ozone and effects of nonmethane hydrocarbons, J. Geophys. Res., 103, 10757-10767, 1998.

Wania, R., Ross, I., and Prentice, I. C.: Implementation and evaluation of a new methane model within a dynamic global vegetation model: LPJ-WHyMe v1.3., Geoscientific Model Development Discussions, accepted, 2010.

Wania, R., Ross, I., and Prentice, I. C.: Integrating peatlands and permafrost into a dynamic global vegetation model: I. Evaluation and sensitivity of physical land surface processes, Global Biogeochem. Cy., 23, 3, GB3014, doi:10.1029/2008GB003412, 2009.

Warneck, P.: Chemistry of the natural atmosphere, 2nd ed., International Geophysics Series, Academic Press, New York, 1999.

Warwick, N. J., Bekki, S., Nisbet, E. G., and Pyle, J. A.: Impact of a hydrogen economy on the stratosphere and troposphere studied in a 2-d model, Geophys. Res. Lett., 31, L05107, doi:05110.01029/02003g1019224, 2004.

Werner, C., Butterbach-Bahl, K., Haas, E., Hickler, T., and Kiese, R.: A global inventory of $\mathrm{N}_{2} \mathrm{O}$ emissions from tropical rainforest soils using a detailed biogeochemical model, Global Biogeochem. Cy., 21, GB3010, doi:3010.1029/2006GB002909, 2007.

Weitz, A. M., Veldkamp, E., Keller, M., Neff, J., and Crill, P. M.: Nitrous oxide, nitric oxide, and methane fluxes from soils following clearing and burning of tropical secondary forest, J. Geophys. Res., 103, 28047-28058, 1998.

Wiberley, A. E., Linskey, A. R., Falbel, T. G., and Sharkey, T. D.: Development of the capacity for isoprene emission in kudzu, Plant Cell Environ., 28, 898-905, 2005.

Wild, O. and Prather, M. J.: Excitation of the primary tropospheric chemical mode in a global three-dimensional model, J. Geophys. Res., 105, 24647-24660, 2000.

Wilkinson, M., Monson, R. K., Trahan, N., Lee, S., Brown, E., Jackson, R. B., Polley, H. W., Fay, P. A., and Fall, R.: Leaf isoprene emission rate as a function of atmospheric $\mathrm{CO}_{2}$ concentration, Glob. Change Biol., 15, 1189-1200, doi:10.1111/j.13652486.2008.01803.x, 2009.

Williams, J. R., Jones, C. A., Kiniry, J. R., and Spanel, D. A.: The EPIC crop growth model, Transactions of the ASAE, 32, 497$511,1989$.

Wilson, R. A. J.: A reexamination of fire spread in free burning porous fuel beds, INT-289, Ogden, UT, 1982.

Wittig, V. E., Ainsworth, E. A., and Long, S. P.: To what extent do current and projected increases in surface ozone affect photosynthesis and stomatal conductance of trees? A meta-analytic review of the last 3 decades of experiments, Plant Cell Environ., 30, 1150-1162, 2007.

Wooster, M. J., Roberts, G., Perry, G. L. W., and Kaufman, Y. J.: Retrieval of biomass combustion rates and totals from fire radiative power observations: FRP derivation and calibration relationships between biomass consumption and fire radiative energy, J. Geophys. Res., 110, D24311, doi:24310.21029/22005JD006318, 2005.

Wu, S., Mickley, L. J., Jacob, D. J., Logan, J. A., and Yantosca, R. M.: Why are there large differences between models in global budgets of tropospheric ozone?, J. Geophys. Res., 112, D05302, doi:05310.01029/02006JD00780, 2007.

Wu, S., Duncan, B. N., Jacob, D. J., Fiore, A. M., and Wild, O.: Chemical nonlinearities in relating intercontinental ozone pollution to anthropogenic emissions, Geophys. Res. Lett., 36, L05806, doi:10.1029/2008GL036607, 2009.

$\mathrm{Xu}-\mathrm{Ri}$ and Prentice, I. C.: Terrestrial nitrogen cycle simulation with a dynamic global vegetation model, Glob. Change Biol., 14, 1745-1764, doi:1740.1111/j.1365-2486.2008.01625.x, 2008.

Yonemura, S., Kawahima, S., and Tsurata, H.: Carbon monoxide, hydrogen, and methane uptake by soils in a temperate arable field and a forest, J. Geophys. Res., 105, 14347-14362, 2000.

Young, P. J., Arneth, A., Schurgers, G., Zeng, G., and Pyle, J. A.: The $\mathrm{CO}_{2}$ inhibition of terrestrial isoprene emission significantly affects future ozone projections, Atmos. Chem. Phys., 9, 27932803, 2009, http://www.atmos-chem-phys.net/9/2793/2009/.

Zaehle, S., Bondeau, A., Carter, T. R., Cramer, W., Erhard, M., Prentice, I. C., Reginster, I., Rounsevell, M. D. A., Sitch, S., Smith, B., Smith, P. C., and Sykes, M.: Projected changes in terrestrial carbon storage in europe under climate and land-use change, 1990-2100, Ecosystems, 10, 380-401, 2007.

Zaehle, S., Friend, A. D., Dentener, F., Friedlingstein, P., Peylin, P., and Schulz, M.: Carbon and nitrogen cycle dynamics in the OCN land surface model, II: The role of the nitrogen cycle in the historical terrestrial carbon balance, Global Biogeochem. Cy., doi:10.1029/2009GB003522, in press, 2010.

Zaehle, S. and Friend, A. D.: Carbon and nitrogen cycle dynamics in the O-CN land surface model, I: Model description, sitescale evaluation and sensitivity to parameter estimates, Global Biogeochem. Cy., doi:10.1029/2009GB003521, in press, 2010.

Zhang, L. M., Brook, J. R., and Vet, R.: On ozone dry deposition with emphasis on non-stomatal uptake and wet canopies, Atmos. Environ., 36, 4787-4799, 2002.

Zhang, Y., Cheng, W., and Riseborough, D. W.: Transient projections of permafrost distribution in Canada during the 21st century under scenarios of climate change, Global Planet. Change, 60, 443-456, 2008.

Zhuang, Q., McGuire, A. D., Melillo, J. M., Clein, J. S., Dargaville, R. J., Kicklighter, D. W., Myneni, R. B., Dong, J., Romanovsky, V. E., Harden, J., and Hobbie, J. E.: Carbon cycling in extratropical terrestrial ecosystems of the northern hemisphere during the 20th century: A modeling analysis of the influences of soil thermal dynamics, Tellus B, 55, 751-776, 2003.

Zhuang, Q., Melillo, J. M., Kicklighter, D. W., Prinn, R. G., McGuire, A. D., Steudler, P. A., Felzer, B. S., and Hu, S.: Methane fluxes between terrestrial ecosystems and the atmosphere at northern high latitudes during the past century: A retrospective analysis with a process-based biogeochemistry model, Global Biogeochem. Cy., 18, GB3010, doi:3010.1029/2004GB002239, 2004.

Ziska, L. H. and Bunce, J. A.: Predicting the impact of changing $\mathrm{CO}_{2}$ on crop yields: Some thoughts on food, New Phytol., 175, 607-617, 2007. 